\title{
SIMPLE PULMONARY STENOSIS
}

\section{PULMONARY VALVULAR STENOSIS WITH A CLOSED VENTRICULAR SEPTUM}

\author{
BY \\ MAURICE CAMPBELL \\ From the Cardiac Dept., Guy's Hospital, and the Institute of Cardiology \\ Received January 24, 1954
}

Jimmy appeared to be a normal child and when he was three and had bronchitis his parents were shocked to be told that he had congenital heart disease. He was, however, able to do everything like other boys and seemed so healthy that they thought less and less of this, until when he was about 12 he became more breathless on playing games: he had gradually developed highcoloured cheeks and his face and hands went blue in cold weather more easily than other children. When he was 18 he began to find life difficult for the first time: he could not cycle or run so well and became blue with exertion as well as with cold. Within a few months he could not walk so far and could no longer manage his work.

This is a characteristic story of a child with simple pulmonary stenosis which is defined as congenital pulmonary valvular stenosis with a closed ventricular septum. The picture is, however, very varied for some patients remain well and acyanotic for much longer, and others become cyanotic and disabled earlier.

\section{The Present Position}

Brown (1939) in Congenital Heart Disease described several features of simple pulmonary stenosis. It was regarded as rare by most physicians, and by Taussig (1947)—probably because her work was mainly with infants where it is less easy to diagnose-as very rare. Currens et al. (1945) reported 11 cases from their hospital records, and since then Selzer et al. (1949) and Allanby and Campbell (1949) have published series of their own and have shown that the condition is common. Brown, perhaps, laid too little stress on the place of the patent foramen ovale in producing cyanosis-a point that was emphasized in the last two papers.

Brock and Campbell (1950) have discussed the surgical treatment, and Dow et al. (1950) and Soulié et al. (1953) have proved that this diagnosis may be correct even in patients with slight symptoms. Abrahams and Wood (1951), in a valuable paper, have emphasized the importance of simple physical signs in the diagnosis and of the $a$ wave in the jugular venous pulse, and the fundamental differences between slight and severe cases.

The object of this paper is to correlate the symptoms, the size of the heart, the electrocardiographic evidence of right ventricular strain, the findings at cardiac catheterization, and the time when cyanosis may develop, so that the prognosis and the indications for pulmonary valvotomy may be better understood.

\section{INCIDENCE}

Among my 670 patients with cyanotic congenital heart disease, seen from 1947 to 1951 , there were 41 examples $(6 \%)$ and among 460 acyanotic patients there were $72(16 \%)$. This gives a combined incidence of 10 per cent among all cases of congenital heart disease, a figure that agrees with the 12.5 per cent in the experience of Wood (1950a). 
Sex and Age Incidence. The body of this paper refers only to 75 patients where the diagnosis was proved, but in this section 25 others where the clinical diagnosis seemed certain have been added. There was very little difference in the sex incidence, 47 being male and 53 female.

The age incidence was much higher than that for cyanotic congenital heart disease in general, nearly one-third being over 20 and a few between 30 and 50 years of age. There was not a great difference between the cyanotic and acyanotic patients (see Table I) except that six of the seven over 30 were acyanotic. The diagnosis was made less often under 5 years, unless there was cyanosis to draw attention to it.

TABLE I

Age and Sex Incidence of Simple Pulmonary Stenosis

\begin{tabular}{|c|c|c|c|c|c|c|c|c|c|c|c|c|c|}
\hline Age in years & $\begin{array}{c}0 \\
\text { to } \\
4\end{array}$ & $\begin{array}{c}5 \\
\text { to } \\
9\end{array}$ & $\begin{array}{l}10 \\
\text { to } \\
14\end{array}$ & $\begin{array}{l}15 \\
\text { to } \\
19\end{array}$ & $\begin{array}{l}20 \\
\text { to } \\
24\end{array}$ & $\begin{array}{l}25 \\
\text { to } \\
29\end{array}$ & $\begin{array}{l}30 \\
\text { to } \\
34\end{array}$ & $\begin{array}{l}35 \\
\text { to } \\
39\end{array}$ & $\begin{array}{l}40 \\
\text { to } \\
44\end{array}$ & 45 & Male & Female & Total \\
\hline $\begin{array}{l}\text { Cyanotic } \\
\text { Acyanotic }\end{array}$ & $\begin{array}{l}6 \\
3\end{array}$ & $\begin{array}{r}7 \\
16\end{array}$ & $\begin{array}{r}6 \\
15\end{array}$ & $\begin{array}{r}6 \\
11\end{array}$ & $\begin{array}{l}5 \\
8\end{array}$ & $\begin{array}{l}5 \\
5\end{array}$ & $\begin{array}{l}1 \\
2\end{array}$ & $\overline{1}$ & $\overline{2}$ & $\overline{1}$ & $\begin{array}{l}15 \\
32\end{array}$ & $\begin{array}{l}21 \\
32\end{array}$ & $\begin{array}{l}36 \\
64\end{array}$ \\
\hline Total .. & 9 & 23 & 21 & 17 & 13 & 10 & 3 & 1 & 2 & 1 & 47 & 53 & 100 \\
\hline
\end{tabular}

Making allowance for the age at which cyanosis developed, the proportion with central cyanosis increases steadily with age, from 19 per cent at 5 years to 36 per cent at 25 years, showing that the number becoming cyanotic outweighs the greater mortality among the cyanotic.

\section{The Presence or Absence of Cyanosis}

The distinction between cyanotic and acyanotic patients can be easy, for one may show gross cyanosis at rest and another no trace of cyanosis so that the differential diagnosis is from septal defects and other acyanotic lesions. There are, however, many patients without central cyanosis at rest but with some story of cyanosis: it is often peripheral, but a right-to-left shunt through a patent foramen ovale that develops only with exercise may be hard to exclude by simple clinical examination.

We have classified patients as cyanotic or acyanotic according to our clinical judgment of whether there was central cyanosis at rest when they came up as out-patients. Generally those who were classed as acyanotic had an arterial $\mathrm{O}_{2}$ saturation of 93 per cent or higher and the cyanotic had one of 92 per cent or lower. We have, however, counted one patient as cyanotic, although her arterial $\mathrm{O}_{2}$ saturation in the ward was 94 per cent (see Case 12), and two as acyanotic where it was 92 per cent, though we think that they (and some others) developed a right-to-left shunt through an unsealed foramen ovale on exertion.

In most forms of congenital heart disease the distinction between cyanotic and acyanotic cases is so vital that we analysed these two groups separately, and intended to describe them separately, but the findings are so similar that it would have led to much unnecessary repetition.

\section{Patients without Central Cyanosis at Rest}

There were 44 patients in this group and 30 have had pulmonary valvotomy. In two the diagnosis was confirmed by necropsy and all the others had cardiac catheterization, the smallest systolic pressure gradient across the pulmonary valve being from 35 to $14 \mathrm{~mm}$. $\mathrm{Hg}$.

Fifteen of the 44 showed no cyanosis and gave no history of it at any time. Peripheral cyanosis was reported with cold weather in 14 and (generally to a lesser extent) with exertion in another 15. It is uncertain how many of these developed right-to-left shunts during exercise; five of them almost certainly did so. One was sent to hospital because he became so blue when playing fives for his school that a master made him see the doctor: probably this was one of the first occasions when a fit young man developed a right-to-left shunt, and although his symptoms were trivial and his 
heart of normal size, there was deep T inversion across the chest leads to V4 and a systolic pressure in the right ventricle of $148 \mathrm{~mm}$. Hg.

When there is no central cyanosis, there is no polycythæmia and the hæmoglobin is generally between 80 and 100 per cent. The two highest figures were 106 and 109 per cent in patients who had arterial $\mathrm{O}_{2}$ saturations of 97 per cent; both emphasized that cold weather made them more cyanotic than exertion, but probaby they had a right-to-left shunt on exertion. The numbers included as cyanotic tend, therefore, to under-estimate the proportion where there may at times be such a shunt.

\section{Patients with Central Cyanosis at Rest}

There were 31 patients who were cyanotic at rest. In 11 the diagnosis was confirmed post mortem; six of these had an operation, and these and two others had cardiac catheterization as well. The other 20 have all had an operation which confirmed the presence of valvular stenosis. All have had catheterization as well, except two where (as in many others) pressure gradients across the pulmonary valve and differential pressures between the two ventricles were found at operation, so that the diagnosis is reasonably certain in all. Additional abnormalities may be present in a few, e.g. one is known to have a pulmonary vein draining into the right atrium, but not, we think, in many. Some with left-to-right shunts in addition are described shortly (see p. 296), and recently we have seen one patient with congenital aortic stenosis and incompetence also.

The cyanosis is often severe. The arterial $\mathrm{O}_{2}$ saturation was under 60 per cent in three, between 68 and 84 per cent in eleven, and above 85 per cent in eleven. The range of cyanosis seems deeper in Fallot's tetralogy than in simple pulmonary stenosis with an inter-atrial shunt, but this is not supported by the arterial $\mathrm{O}_{2}$ figures-perhaps because few of the early more cyanotic patients with Fallot's tetralogy had catheterization. In Fallot's tetralogy 80 per cent had an arterial $\mathrm{O}_{2}$ saturation between 62 and 89 with a mean of 77.2 per cent: in simple pulmonary stenosis with an inter-atrial shunt it was between 68 and 90 with a mean of $77 \cdot 7$ per cent.

It is, however, supported by the polycythæmia and hæmoglobin percentages, which may be greatly increased but generally not as much as in Fallot's tetralogy. Thus the mean hæmoglobin percentage was 120 against 134 in 200 patients with Fallot's tetralogy: the usual range was between 100 and 139 instead of between 120 and 149, and the mode was between 110 and 119 instead of 130 and 139 (Fig. 1 and Table II). Nearly all these patients showed some degree of clubbing of the fingers (see later).

TABLE II

Distribution of the Hæmoglobin Percentage in Simple Pulmonary Stenosis compared with Fallot's TETRALOGY

\begin{tabular}{|c|c|c|c|c|c|c|c|c|c|c|c|c|c|}
\hline & & \multicolumn{10}{|c|}{ Numbers (percentages) with hæmoglobin percentages at this level } & \multirow[b]{2}{*}{ Mean } & \multirow[b]{2}{*}{ Usual range } \\
\hline & & $\begin{array}{l}\text { Up } \\
\text { to } \\
89\end{array}$ & $\begin{array}{l}90 \\
\text { to } \\
99\end{array}$ & $\begin{array}{c}100 \\
\text { to } \\
109\end{array}$ & $\begin{array}{c}110 \\
\text { to } \\
119\end{array}$ & $\begin{array}{c}120 \\
\text { to } \\
129\end{array}$ & $\begin{array}{c}130 \\
\text { to } \\
139\end{array}$ & $\begin{array}{c}140 \\
\text { to } \\
149\end{array}$ & $\begin{array}{l}150 \\
\text { to } \\
159\end{array}$ & $\begin{array}{c}160 \\
\text { to } \\
169\end{array}$ & $\begin{array}{c}170 \\
\text { and } \\
\text { above }\end{array}$ & & \\
\hline $\begin{array}{l}\text { P.V.S. (pure) } \\
\text { P.V.S. with P.F.O. } \\
\text { Fallot's tetralogy }\end{array}$ & $\begin{array}{l}. . \\
\cdots \\
\cdots\end{array}$ & $\begin{array}{r}47 \\
3 \\
1\end{array}$ & $\begin{array}{r}34 \\
13 \\
3\end{array}$ & $\begin{array}{r}19 \\
17 \\
8\end{array}$ & $\overline{23}$ & $\begin{array}{l}\overline{13} \\
16\end{array}$ & $\begin{array}{l}\overline{13} \\
23\end{array}$ & $\begin{array}{r}-8 \\
17\end{array}$ & $\begin{array}{l}\overline{10} \\
17\end{array}$ & $\frac{-}{3}$ & $\frac{-}{3}$ & $\begin{array}{r}91 \\
120 \\
134\end{array}$ & $\begin{array}{r}84-101 \\
100-139 \\
120-149\end{array}$ \\
\hline
\end{tabular}

The Onset of Cyanosis. This is very variable and yet a certain pattern becomes evident. In the ten cyanotic patients who were under 10 years of age (average 5.5 years) cyanosis had always started in the first 4 years of life and in three had been present from birth, the average time of onset being at the age of 2 years. In the ten between 10 and 19 (average 14.8 years) it had become apparent at various times from 1 to 14 years and the average time of onset was 7 years. In the eleven between 20 and 33 (average 24.5 years) it was less easy to get a clear story of the onset of cyanosis, as often it seemed to have started at one time and become worse some years later: the usual time of onset was between 12 and 16 (average $14 \cdot 4$ years). 


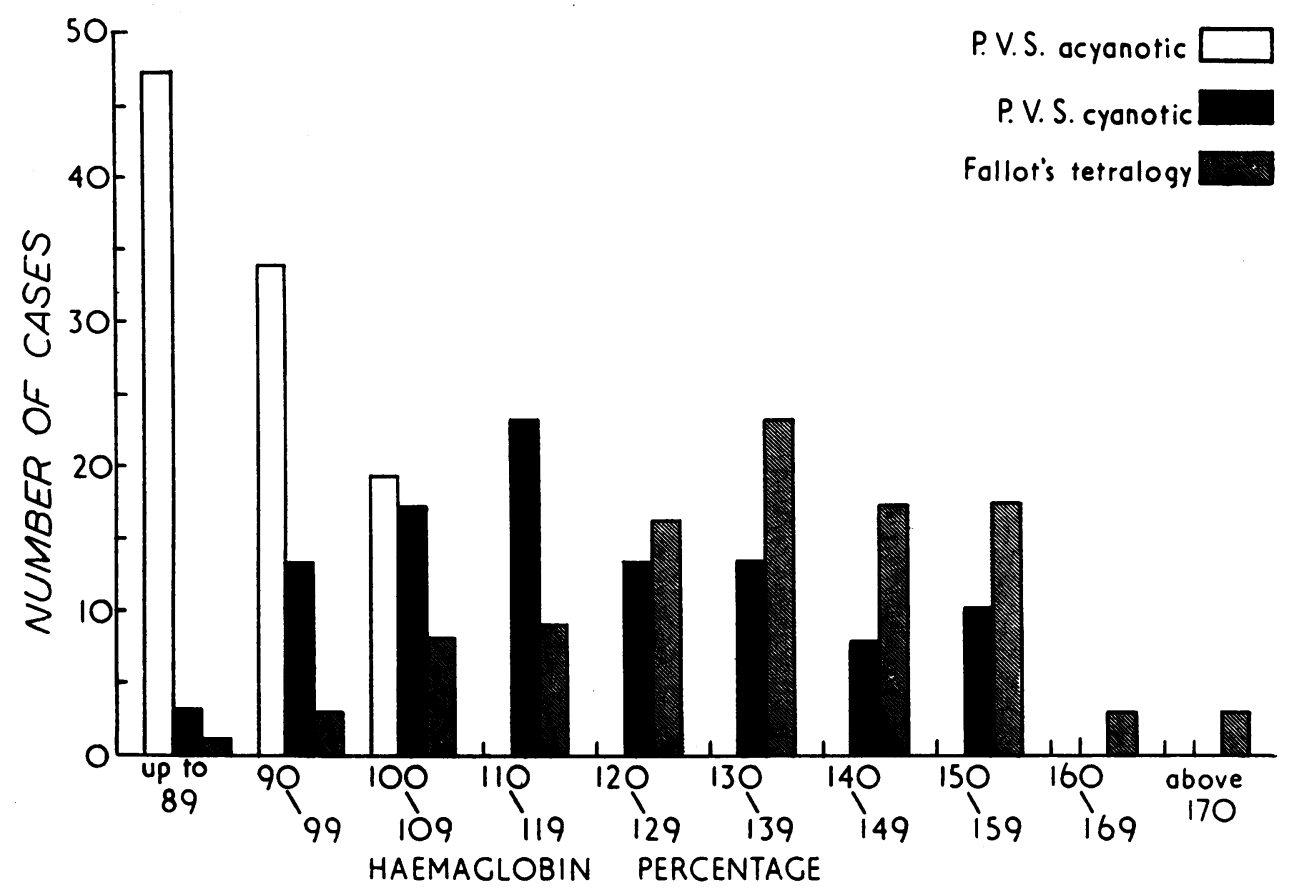

FIG. 1.-Chart contrasting the distribution of the hæmoglobin percentage in simple pulmonary stenosis with that in Fallot's tetralogy. The acyanotic cases show little or no increase, only a few being between 100 and 109 per cent. The range of the cyanotic cases is well below that for Fallot's tetralogy; particularly, there are more patients with percentages between 90 and 119 .

This means that in the older patients cyanosis had started a good deal later but had also been present for longer. We have seen some patients go downhill rapidly after the onset of central cyanosis but many maintain their condition or lose ground only slowly, sometimes in the older patients for 10 years but for less than 5 years in half these patients. One woman who probably develops a right-to-left shunt on exertion has been an out-patient for 20 years and is not getting much worse. Nevertheless, a long history of cyanosis without obvious central cyanosis at rest generally means that it is peripheral.

The Right-to-Left Shunt. The polycythæmia and the arterial oxygen show that the right-toleft shunt is often small. The 20 cases where the findings at catheterization were complete enough to calculate it can be divided into two groups- 9 where the arterial $\mathrm{O}_{2}$ saturation was generally under 70 and averaged 66 per cent and 11 where it was over 80 and averaged 87 per cent. When the arterial $\mathrm{O}_{2}$ saturation averaged 87 per cent the systemic flow was 3 litres, the pulmonary flow 2.3 litres, and the right-to-left shunt 0.7 litres a minute. On the other hand when the arterial $\mathrm{O}_{2}$ saturation averaged 66 per cent the systemic flow was 3 litres, the pulmonary flow was only 1.3 litres, and the right-to-left shunt as much as 1.7 litres a minute. Many of these patients could do very little but still the systemic flow was not greatly reduced (see later).

\section{Physical Signs}

The diagnosis of simple pulmonary stenosis should often be easy. The fundamental physical signs are the systolic murmur and thrill best heard in the pulmonary area, with a pulmonary second sound that is normal or diminished but never increased. There may be nothing else but if so, and 
particularly if there is no right ventricular preponderance in the electrocardiogram, the stenosis is slight and of little importance at the time.

Even when there is no enlargement of the heart as a whole, some prominence of the right ventricle on radioscopy and a prominent pulmonary arc (Fig. 2 and 3) with dilatation that often spreads to the left pulmonary artery (Fig. 5) are early signs. The pulsation that may be seen in this dilated artery may be misleading. For example, a girl, aged 23, had the classical signs of pulmonary stenosis but without right ventricular preponderance or any cardiac enlargement (see Fig. 6C and 9). She was free from symptoms and has remained well for six years. On radioscopy, however, pulsation in the large left pulmonary artery was always so striking that an increased pulmonary blood flow was suspected and catheterization was arranged. This confirmed the clinical diagnosis with pressures of $60 / 4$ in the right ventricle and of $21 / 8$ in the pulmonary trunk. This shows, as was stated by Taussig (1947), that moderate pulsation which does not, however, extend far down the pulmonary artery does not exclude a mild but significant degree of pulmonary stenosis.

Wood (1950b) has emphasized the importance of the $a$ wave in the jugular pulse, and this is not found unless the stenosis is moderately severe. A giant $a$ wave (see p. 285) and a large heart are relatively late signs and then the pulmonary second sound may be faint and the thrill may be hard to feel.

When there is cyanosis there is the added difficulty of excluding other forms of pulmonary stenosis, specially Fallot's tetralogy. In the latter, cyanosis generally starts before eighteen months, while in the former it may start much later, often not till the patient is nearing or past twenty. Peripheral cyanosis is, of course, not evidence of heart disease, but it is common in these patients.

Abrahams and Wood (1951) have described the moon facies in these patients. They certainly stand out from many others with congenital heart disease by their good physique and have not the small, pinched face that is so common in children who have been disabled from infancy. They seem, however, to be of all types and builds, a few being thin and under-developed, the majority normally developed, and a proportion, which seems to be more than would be expected by chance, unusually well-developed with a broad chest and a rather rounded broad face.

Clubbing of the Fingers and Toes. Some degree of clubbing was present in nearly all the cyanotic patients but often less than in those with Fallot's tetralogy or other cyanotic lesions. This may sometimes be because the shunt is small but even when it is large the clubbing is often less than expected, probably because the shunt has not been present for so long nor from the early stage when the child was growing rapidly. When the cyanosis dates from infancy, the clubbing is generally severe and characteristic.

The best classification seems the simple one, into severe, moderate, and slight degrees because generally all the features can be recognized even in the early stages if one looks carefully. Clubbing was severe in 15 of the 31 cases, though in 6 of these the broadening of the fingers was less than the curvature of the nails. In another 6 it was moderate, generally with little broadening of the terminal phalynx. In 10 it was slight, mainly the skin changes and localized cyanosis without much curvature or broadening. We have seen clubbing follow the onset of cyanosis and, even in patients of 20, it can become severe within a year, as is well known in other types of clubbing of the fingers. As might be expected, there was no clubbing of the fingers and toes in the acyanotic patients, though two with arterial $\mathrm{O}_{2}$ saturations of 93 per cent possibly showed a very early stage of it.

Squatting. Squatting is unusual in patients with simple pulmonary stenosis. It would not be expected in the acyanotic, and none of the 44 squatted. Even among the cyanotic it is much less common than in Fallot's tetralogy where it is found in 85 per cent, but 6 of the 31 squatted at some time. In two the story was characteristic and dated from the time of first walking or soon after. A third squatted until he was 4 but then gave it up in spite of increasing cyanosis and disability, and the fourth did so occasionally. The remaining two started to squat when they became cyanotic at 7 and 18 years of age respectively. de Balsac et al. (1954) found it in as many as 30 per cent of their patients. 


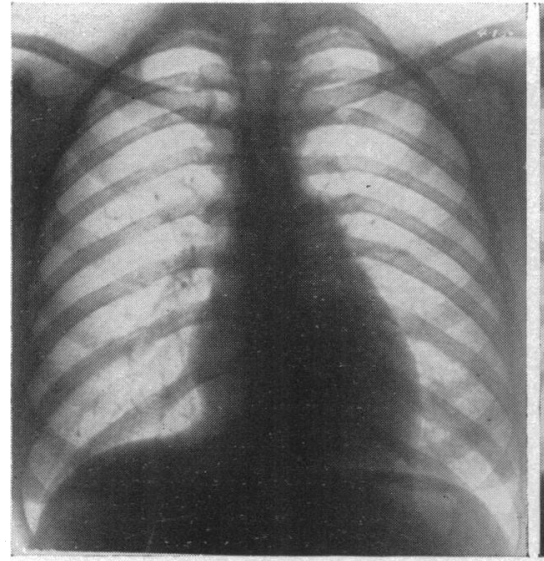

A

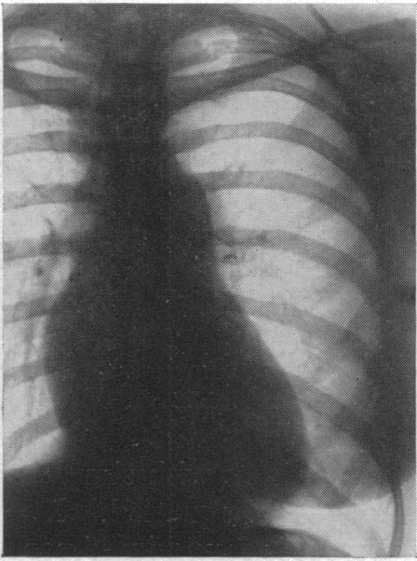

B

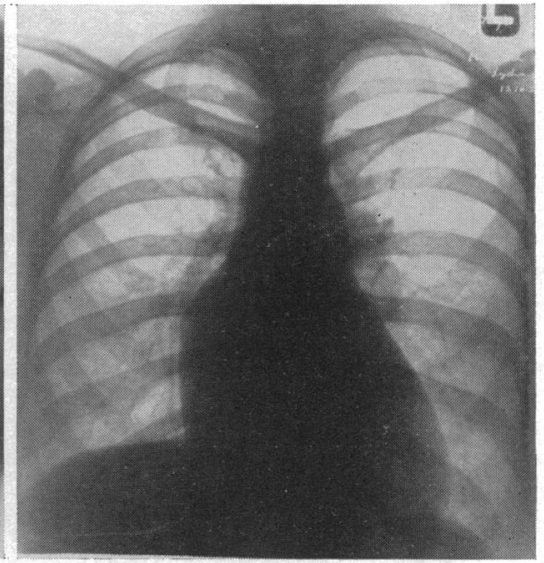

C

FIG. 3.-Three medium-sized hearts from young adults with simple pulmonary stenosis. In (A) the left border had become almost straight with the increasing size, but in (B) and (C) the heart is longer and the concave bay below the pulmonary arc is restored. (A) From an acyanotic girl of 17 with a c.t.r. of $49(12 \cdot 3 / 25 \cdot 6 \mathrm{~cm}$.). (B) From a cyanotic girl of 25 with a c.t.r. of $53(13.9 / 26.4 \mathrm{~cm}$.). (C) From a cyanotic girl of 26 with a c.t.r. of 55 $(14.6 / 26.6 \mathrm{~cm}$.). The right ventricular systolic pressures were between 122 and $165 \mathrm{~mm}$. $\mathrm{Hg}$. Cases O551, 1017 , and $\mathrm{H} 168$.

\section{The Shape AND Size of THE Heart}

stages. This influences the shape, and Fig. 2-7 show some common types. The commonest is the normal-sized heart with a large pulmonary trunk, making the pulmonary arc more prominent than the aortic knuckle, often with, but often without, some dilatation of the left pulmonary artery (Fig. 2); hearts that are becoming rather larger are seen in Fig. 3. The right border is often prominent and rounded. The increasing size may make the left border almost straight and

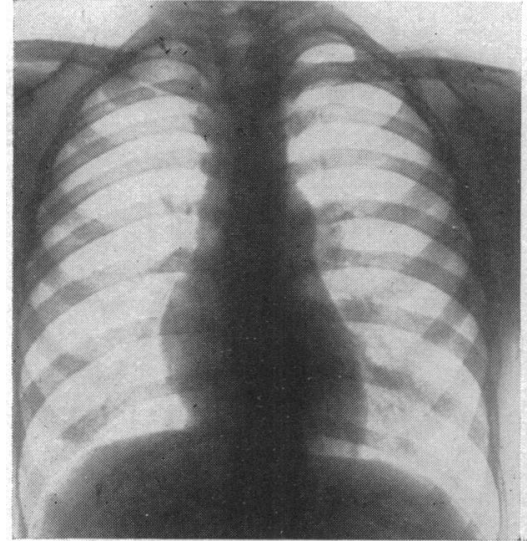

A

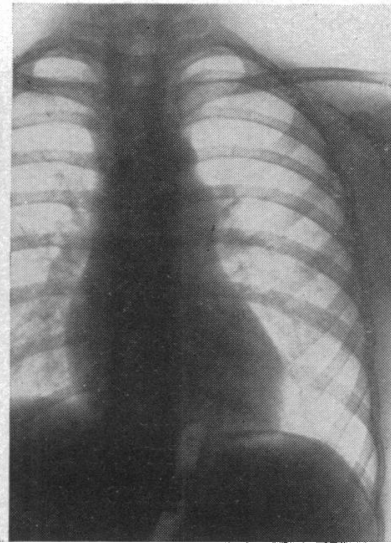

B

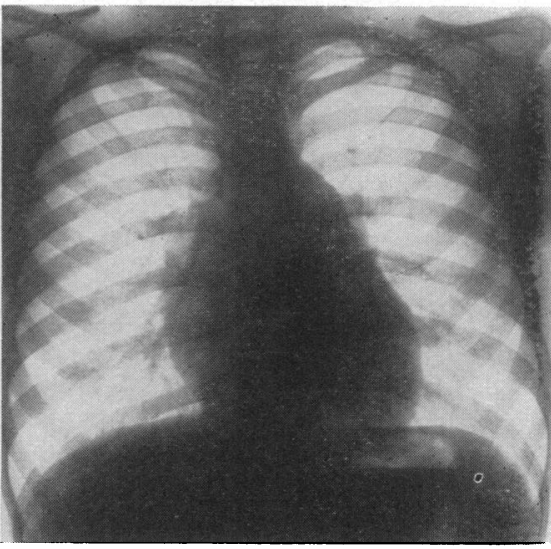

C

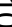
oung adults. (A) From a girl of 12 with a cardiothoracic ratio (c.t.r.) of $45(10 \cdot 2 / 22 \cdot 6 \mathrm{~cm}$.). (B) From boy of 13 with a c.t.r. of $49(11.0 / 22.6 \mathrm{~cm}$.). (C) From a boy of 12 with a c.t.r. of $49(12.5 / 25.6 \mathrm{~cm}$.), but a somewhat larger heart, so that the left border has become straighter. All three were acyanotic but had right ventricular systolic pressures between 105 and $140 \mathrm{~mm}$. Hg. Cases O715, O516, and 0923 . 
to its enlargement downwards again allows it to become prominent (Fig. 3B and C). As the heart becomes still larger, the pulmonary arc is almost hidden (Fig. 4). The heart may be very large even in children (Fig. 7), but then perhaps the shape is less characteristic.

Sometimes the picture is modified by the left, or less often by both pulmonary arteries being unusually prominent. Both the pulmonary trunk and its left branch may be prominent (Fig. 5B) or only the left pulmonary artery (Fig. 5A and C). In Fig. 5C the dilatation has spread unusually far; the patient had few symptoms in spite of a right ventricular pressure of $180 / 0 \mathrm{~mm}$. Sometimes both pulmonary arteries are dilated (Fig. 6). Occasionally the increase in the pulmonary trunk is almost aneurysmal, and this may happen with a heart that is not very large and in a young patient (Fig. 6A).

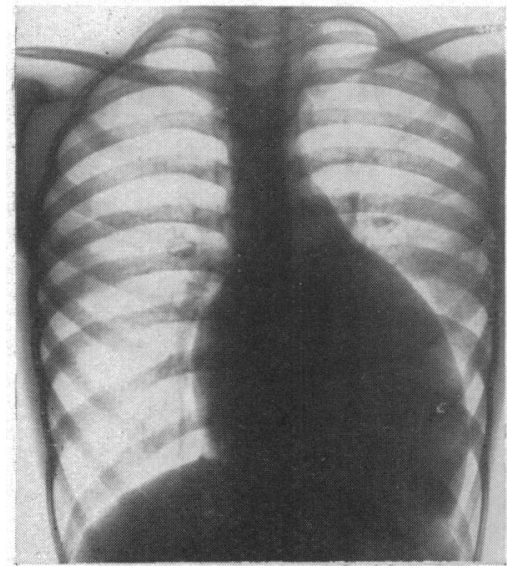

A

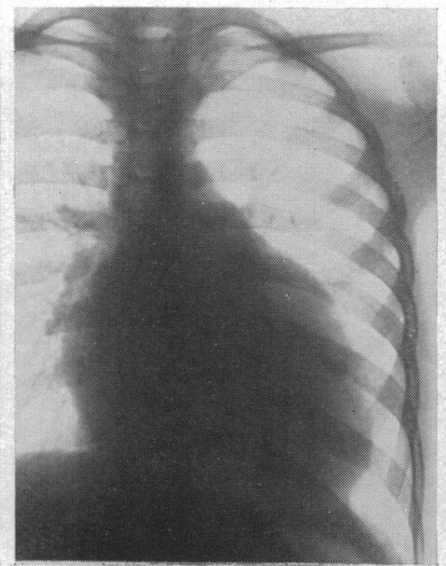

B

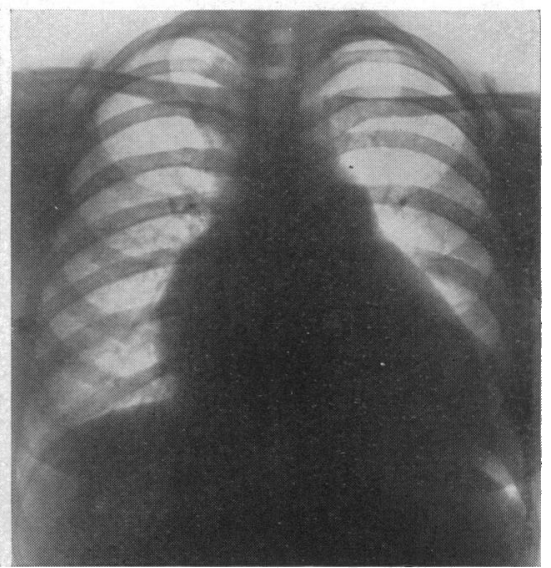

C

FIG. 4.-Three hearts of increasing size in simple pulmonary stenosis where the left border appears more humped though the pulmonary arc is still visible above this. (A) From a cyanotic girl of 12 with a c.t.r. of 64 $(12.5 / 19.5 \mathrm{~cm}$.). (B) From an acyanotic girl of 9 with a c.t.r of $64(12.6 / 19.7 \mathrm{~cm}$.). (C) From an acyanotic woman aged 29 with a c.t.r. of $69(17 \cdot 7 / 25 \cdot 8$ c.). In all three the right ventricular systolic pressure was above $133 \mathrm{~mm}$. Hg. Cases O328, O468, and P272.

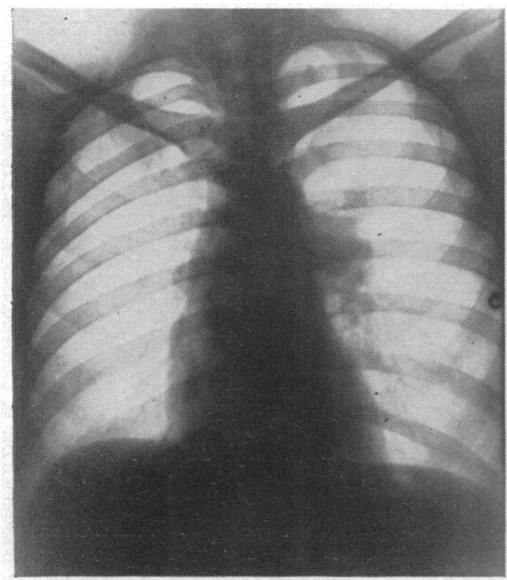

A

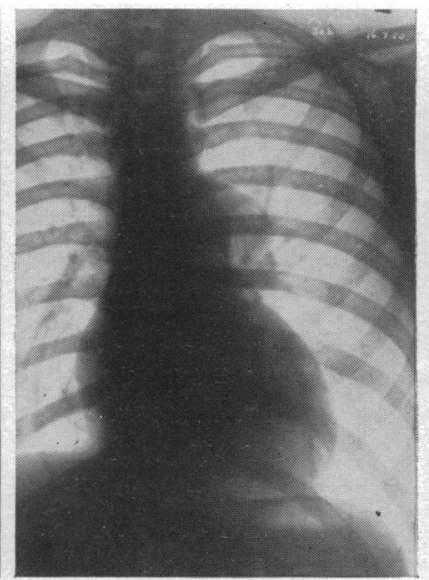

B

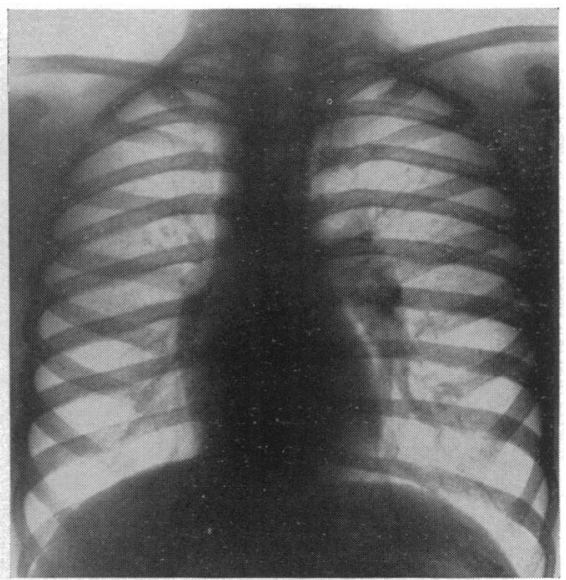

C

FIG. 5.-Unusual dilatation of the left pulmonary artery in simple pulmonary stenosis. (A) From a cyanotic woman of 33 with a c.t.r. of $46(12 \cdot 2 / 26.6 \mathrm{~cm}$.). (B) From an acyanotic boy of 16 with a c.t.r. of $50(15 \cdot 0 / 30 \cdot 0 \mathrm{~cm}$.). (C) Exceptional dilatation of the left pulmonary artery: from an acyanotic boy of 12 with a c.t.r. of 42 $(9 \cdot 0 / 21.5 \mathrm{~cm}$.) and a right ventricular systolic pressure of 180 . In the other two the pressures were 110 and 148 . Cases O931, P293, and P247. 


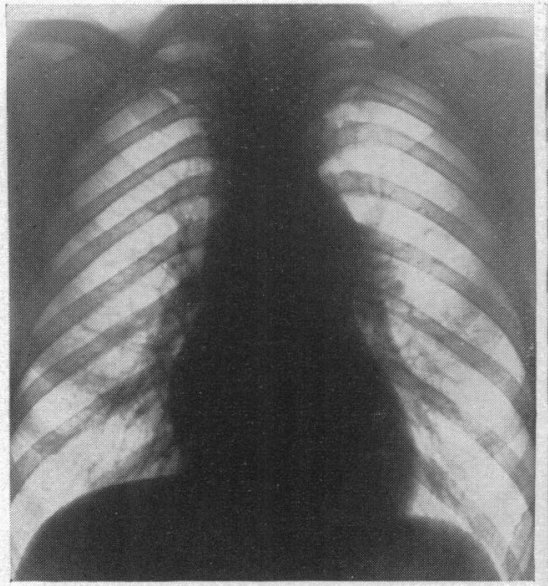

A

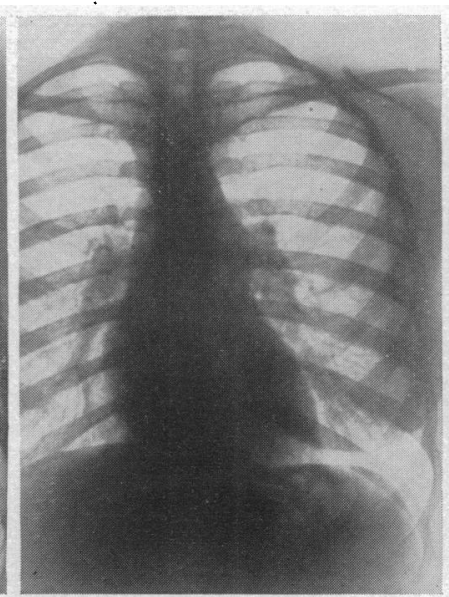

$\mathbf{B}$

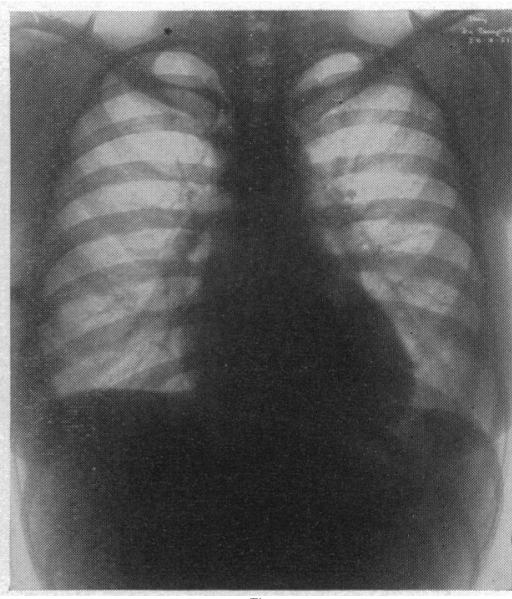

C

Fig. 6.-Dilatation of both left and right pulmonary arteries in simple pulmonary stenosis. (A) Almost aneurysmal dilatation of the pulmonary trunk and the left branch though there were no symptoms; from an acyanotic man of 25 with a c.t.r. of $48(13.9 / 29.0 \mathrm{~cm}$.). (B) Dilatation of the main trunk and both branches; from an acyanotic girl of 19 with a c.t.r. of $45(12 \cdot 2 / 27 \cdot 0 \mathrm{~cm}$.). (C) Some dilatation and pulsation of both pulmonary arteries; from an acyanotic girl of 25 with a c.t.r. of $48(12 \cdot 7 / 26.4 \mathrm{~cm}$.). The right ventricular systolic pressure was only 60 and she was free from symptoms (see text). In the other two the pressure was between $110 \mathrm{and} 120 \mathrm{~mm}$. $\mathrm{Hg}$. Cases H350, O596, and $\mathrm{H} 302$.

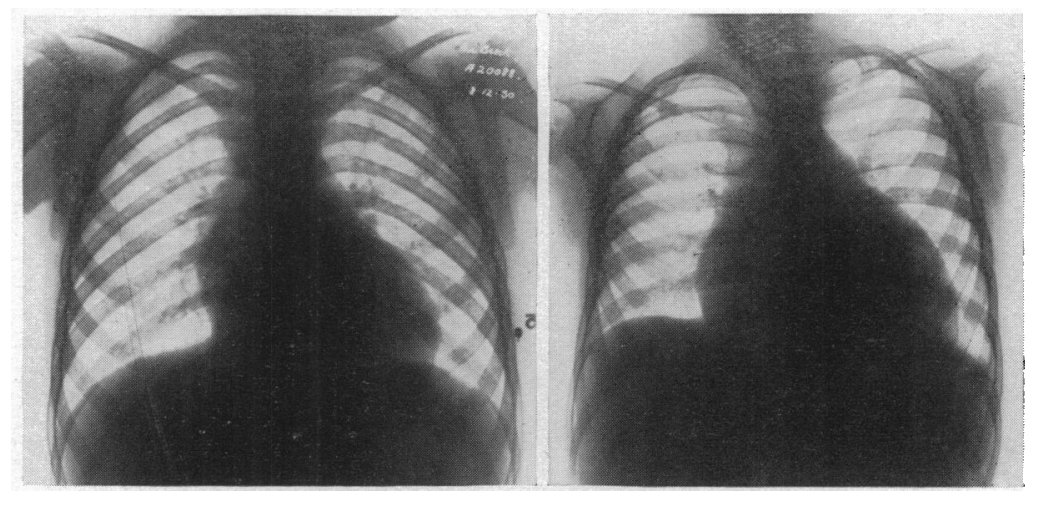

A

B

Fig. 7.-Two hearts of less characteristic shape from children, both of whom were cyanotic and had severe symptoms. (A) From a boy of 8 with a c.t.r. of $57(10 \cdot 7 / 18.8 \mathrm{~cm}$.). (B) From a boy of 4 with a c.t.r. of $68(11 \cdot 2 / 16.6 \mathrm{~cm}$.). The right ventricular systolic pressures were between 115 and 118; both have had successful valvotomy and the hearts are smaller. Cases 1025 and 0897.

The heart was of normal size in more than a third of these patients, though there was always some prominence of the right ventricle on radioscopy. In one-third it was slightly or moderately enlarged and in nearly a third it was greatly enlarged (see Table III). Allanby and Campbell (1949), in a paper based on patients who had died, emphasized the large heart of simple pulmonary stenosis, but this indicates a late and serious stage and the stenosis may be severe with a heart that is little, if at all, enlarged.

Cyanotic Group. The cardiothoracic ratio was 50 per cent or less in 7 of the 31 patients. Generally, these were not the most disabled patients, and the two who were had been fairly well till they were over 20 years of age. In 10 the heart was slightly or moderately enlarged (c.t.r. 5156 per cent). In the other 14 it was very large and in 12 of these the ratio was over 60 per cent. 
In 8 of these the cyanosis and disability dated from early infancy, but in the other 6 , all seriously disabled and three with failure, only since they were in the teens.

Acyanotic Group. The heart tended to be smaller and was of normal size in more than half; four-fifths of the normal-sized hearts but less than one-third of the very large hearts were in the acyanotic group. Even these figures show that large hearts can occur without cyanosis, presumably in patients who can not develop central cyanosis because the foramen ovale is sealed. Most of the

TABLE III

Cardiothoracic Ratios in Simple Pulmonary Stenosis

\begin{tabular}{cccc|c|c|c}
\hline & & & $\begin{array}{c}57 \\
\text { and } \\
\text { over }\end{array}$ & $\begin{array}{r}51 \\
\text { to } \\
56\end{array}$ & $\begin{array}{c}50 \\
\text { and } \\
\text { less }\end{array}$ \\
\hline Cyanotic (31) &.. &.. &.. & 14 & 10 & 7 \\
Acyanotic (44) &. &.. &. & 6 & 14 & 24 \\
\hline Total (75) &.. &.. & 20 & 24 & 31 \\
\hline
\end{tabular}

six with the largest hearts showed even more peripheral cyanosis than was usual. It is difficult to be sure of the natural prognosis of a patient with a large heart because this has been one of the criteria for pulmonary valvotomy. There were, however, six patients who died without operation and in four of these the hearts were large.

Side of the Aortic Arch. There is no tendency for the aortic arch to be right-sided in simple pulmonary stenosis, as it is in a quarter of the patients with Fallot's tetralogy. It was left-sided in all the 31 cyanotic, and in all but one of the 44 acyanotic cases. An incidence of only 1 in 75 means that a right-sided aortic arch is somewhat against the diagnosis.

\section{Electrocardiographic Changes}

Right Ventricular Preponderance. This was found in all the cyanotic group, generally with deep $\mathrm{T}$ inversion across the chest leads to V4 and sometimes to V5 and V6 (Fig. 8). Some early patients

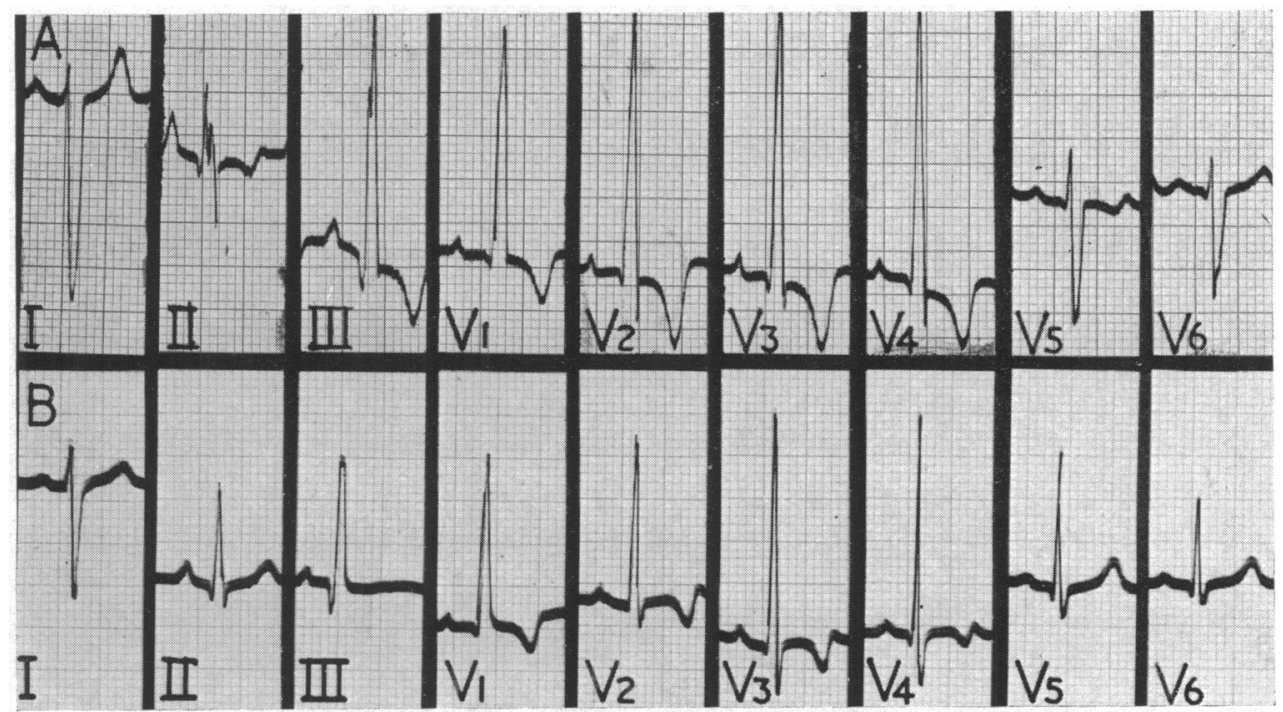

FIG. 8.-The characteristic pattern of $T$ inversion across the chest leads and improvement of this after pulmonary valvotomy. (A) Before operation with T deeply inverted in leads III, VR, VF, and from V1 to V4, and biphasic in V5. (B) Three years after operation, showing considerable improvement though the $\mathrm{T}$ waves are still somewhat inverted or biphasic. Case O468. 
had standard leads only, but they showed such deep T inversion in leads II and III that all or most of them would probably have shown it in the chest leads; if so, it was present in 26 of the 31 and stopped at V3 in 3 only and reached V4 or further in 23 (Table IV), but this pattern was not seen in 5 cases.

TABLE IV

Right Ventricular Preponderance in Simple Pulmonary Stenosis

\begin{tabular}{l|c|c|c|c}
\hline & No R.V.P. & R.V.P. & $\begin{array}{c}\text { T inverted } \\
\text { in V1 only }\end{array}$ & $\begin{array}{c}\text { T inverted } \\
\text { to V4 }\end{array}$ \\
\hline $\begin{array}{l}\text { Cyanotic (31) .. } \because(30) \\
\text { Acyanotic with operations (30) }\end{array}$ & 0 & 2 & 3 & $26^{*}$ \\
Acyanotic with no operation (14) & 4 & 9 & 3 & $\begin{array}{c}18 \dagger \\
0\end{array}$ \\
\hline
\end{tabular}

* T inverted to $\mathrm{V} 3$ only in $3:$ standard leads only in 6 cases.

$+T$ inverted to $V 3$ only in 1 case.

$\ddagger \mathbf{R}=\mathrm{S}$ in V1 in 2 cases and R.V.P. shown only in V3R in 2 cases.

In the acyanotic group this pattern of $T$ inversion across the chest leads is less constant but still common (18 of 44 cases). There was a great difference between those who have had valvotomy and those who have not, but this is mainly because the pattern was taken as an important indication for operation. Among the latter there were 4 who showed no right ventricular preponderance and 4 others where it was of lesser degree than usual (Fig. 9) the R and S waves in V1 being about

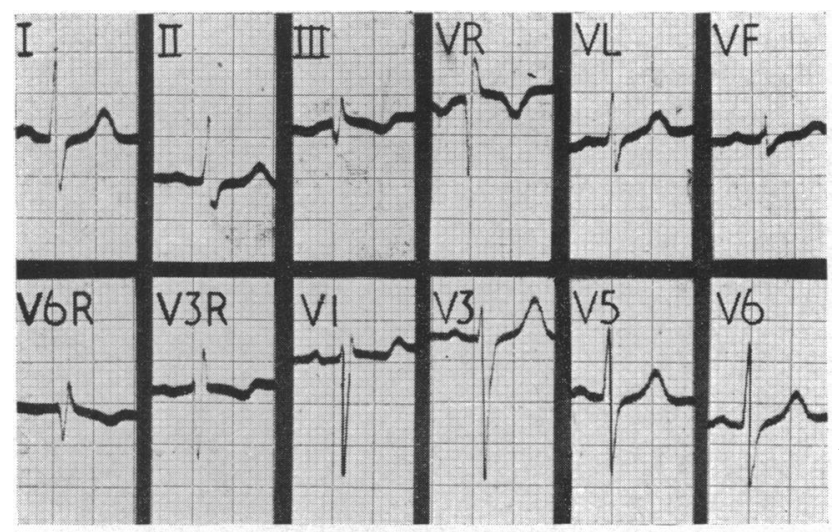

FIG. 9.-Electrocardiogram showing very slight right ventricular preponderance from a patient with no symptoms and a pressure gradient across the pulmonary valve from 60 to $20 \mathrm{~mm}$. Hg. Operation is not indicated when there is so little right ventricular preponderance. Case H302 (see text).

equal, or a predominant $\mathrm{R}$ being found in the right-sided chest leads only. There were none with $T$ inversion across the chest leads and only two with significant $T$ inversion in V1, against 21 of the 29 who had valvotomy.

In all the patients with $\mathrm{T}$ inversion to V4, whether cyanotic or acyanotic, the right ventricular systolic pressure was over 100 and often greatly over this. There were, however, 16 where this pattern was absent although the systolic pressure was over $100 \mathrm{~mm}$. There were 11 acyanotic cases: three of these, with pressures of 155, 146, and 115, had T inversion in V1 only; and the other eight, with pressures of about 150 in two and between 100 and 120 in the remainder, had no more than right ventricular preponderance. There were also 5 cyanotic cases: two children showed right ventricular preponderance only, and the other three, aged 33, 19, and 17, had fairly deep 
$\mathrm{T}$ inversion in V1 but no further. The first had few symptoms but her right ventricular systolic pressure was 97 ; in the second it was very high, 238 , and she was the only one where the heart was large. The third had borne two children and had been fairly well till she was 31 years old, although the right ventricular systolic pressure was 110. The fourth and fifth had pressures of 63 (at operation) and of 140 (at catheterization) respectively.

It is difficult to get a parallel series where no operation has been performed to show the natural history of patients with a high pressure with and without this pattern. Operation has not been advised in two of our patients in spite of pressures over 100 and so far, both are doing well; the absence of this $T$ inversion pattern certainly influenced the decision to delay operation. There was one cyanotic patient (Case 12) where operation was refused, and death followed a year after the finding of a systolic pressure of 135, and during the last year of her life the $T$ inversion spread across from V4 to V6.

This pattern of sharply inverted $\mathrm{T}$ waves in chest leads V1 to V4 always indicates a right ventricular systolic pressure over $100 \mathrm{~mm}$., but its absence does not exclude such a high pressure even when the ventricular septum is closed. It is probably one of the best indications that operation is needed urgently; this was suggested by Marquis (1951) who gave reasons for believing that the pattern developed before clinical deterioration or gross enlargement of the heart, and is supported by de Balsac et al. (1954). It seems, however, that it is not sufficiently sensitive, and that if a right ventricular systolic pressure above $100 \mathrm{~mm}$. indicates operation something else is needed if catheterization is to be avoided. It is known, of course, that the pattern is uncommon in Fallot's tetralogy, although the systolic ventricular pressure is generally about 100 , and this might suggest that it is associated with pressures much higher than $100 \mathrm{~mm}$. It often is, but in this series it was also found in eight patients with pressures between 107 and 125 and was absent in three with pressures between 140 and 160 .

$P-R$ Intervals. Allanby and Campbell (1949) found that the P-R interval averaged 0.21 sec. in their cases coming to necropsy; it is much shorter in the majority at an earlier stage. In 25 of the 31 cyanotic patients, it was within normal limits though rather at the upper range of this (see Table V), for White (1951) says that it averages $0.16 \mathrm{sec}$. in adults and $0.13 \mathrm{sec}$. in children. The

TABLE V

The Size of PII And the Length of the P-R Interval in Simple Pulmonary Stenosis

\begin{tabular}{|c|c|c|c|c|c|c|c|c|c|}
\hline & \multicolumn{9}{|c|}{ Size of PII in $\mathrm{mm}$. } \\
\hline & 1 & 2 & 3 & 4 & 5 & 6 & 7 & 8 & 9 \\
\hline \multirow[t]{3}{*}{$\begin{array}{l}\text { Cyanotic cases (31). } \\
\text { Acyanotic cases (44). }\end{array}$} & $\begin{array}{r}1 \\
10\end{array}$ & $\begin{array}{r}2 \\
19\end{array}$ & $\begin{array}{l}12 \\
10\end{array}$ & $\begin{array}{l}4 \\
2\end{array}$ & $\begin{array}{l}6 \\
2\end{array}$ & $\begin{array}{l}2 \\
1\end{array}$ & $\underline{2}$ & $\begin{array}{l}0 \\
-\end{array}$ & $\underline{2}$ \\
\hline & \multicolumn{9}{|c|}{ Length of $\mathbf{P}-\mathbf{R}$ interval in sec. } \\
\hline & $\begin{array}{l}\text { Up to } \\
0 \cdot 14\end{array}$ & $\begin{array}{l}0 \cdot 15 \\
\text { to } \\
0 \cdot 16\end{array}$ & $\begin{array}{l}0 \cdot 17 \\
\text { to } \\
0 \cdot 18\end{array}$ & $\begin{array}{l}0 \cdot 19 \\
\text { to } \\
0 \cdot 20\end{array}$ & $\begin{array}{l}0.21 \\
\text { to } \\
0.22\end{array}$ & $\begin{array}{c}0.23 \\
\text { to } \\
0.24\end{array}$ & $\begin{array}{l}0.25 \\
\text { to } \\
0.26\end{array}$ & $0 \cdot 27$ & $0 \cdot 31$ \\
\hline $\begin{array}{l}\text { Cyanotic cases (31). } \\
\text { Acyanotic cases (44). }\end{array}$ & $\begin{array}{r}4 \\
13\end{array}$ & $\begin{array}{r}7 \\
10\end{array}$ & $\begin{array}{l}10 \\
12\end{array}$ & $\begin{array}{l}4 \\
7\end{array}$ & $\begin{array}{l}2 \\
0\end{array}$ & $\begin{array}{l}2 \\
1\end{array}$ & $\begin{array}{l}0 \\
1\end{array}$ & 1 & 1 \\
\hline
\end{tabular}

six patients with intervals longer than this, from 0.21 to 0.31 sec., have all died. A prolonged $\mathbf{P}-\mathbf{R}$ interval, therefore, often signifies a serious prognosis.

Among the acyanotic patients the P-R interval was generally normal. There were only two where it was longer than $0.20 \mathrm{sec}$., one with only slight symptoms and a moderately raised pressure in the right ventricle $(0.23 \mathrm{sec}$.), and one who had a pressure of $140 / 21$ and has done well after operation $(0.26 \mathrm{sec}$.). 
$P$ Wave in Lead II. Many of these patients had a large, and some an exceptionally large, PII. Brown (1939) said that PII was often large in pulmonary stenosis, and Wood and Selzer (1939) said that the tall pointed $\mathrm{P}$ was rarely seen except with pulmonary stenosis, tricuspid stenosis, and chronic cor pulmonale. Campbell (1948) found PII was generally pointed and often from 3 to $5 \mathrm{~mm}$. tall, and Baker et al. (1949) found it averaged $4.5 \mathrm{~mm}$. and was generally between 3 and $7 \mathrm{~mm}$. in 50 cases of Fallot's tetralogy submitted to subclavian-pulmonary anastomosis. Allanby and Campbell (1949) found it even larger in simple pulmonary stenosis coming to necropsy, where

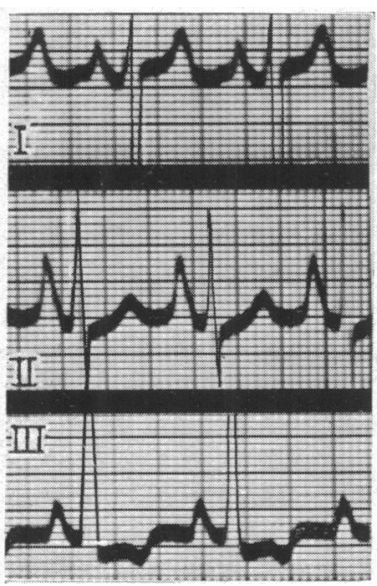

FIG. 10. - Electrocardiogram showing an exceptionally large pointed PII and the predominant SI and RIII that indicate right ventricular preponderance. Case 13 (P133). it averaged as much as $5.8 \mathrm{~mm}$. and could be as large as $9 \mathrm{~mm}$. Zuckermann et al. (1951) and Joly et al. (1952) have recently emphasized the large $\mathbf{P}$ wave in these cases; the latter state that the congenital $P$ wave is relatively uncommon in Fallot's tetralogy but much more common in pulmonary atresia and in the "grandes trilogies," i.e. the cyanotic cases with the pressure higher in the right than in the left ventricle.

The maximum normal size is given as $3 \mathrm{~mm}$. by White (1951) and as $2 \mathrm{~mm}$. by Wood (1950b); Chamberlain and Hay (1939) give an average size of 1.7 with a maximum of $2.6 \mathrm{~mm}$. in the second and third decades. In our cyanotic cases PII was less than $3 \mathrm{~mm}$. in only 3 of the 31 ; in 22 it was $3-5 \mathrm{~mm}$. and in six $6-9 \mathrm{~mm}$. (Table V and Fig. 10). In the acyanotic cases it was sometimes large but not nearly as large as this. In 29 of the 44 it was less than $3 \mathrm{~mm}$., in 14 it was $3-5 \mathrm{~mm}$., and in one only it was $6 \mathrm{~mm}$.

The four patients with the largest $P$ waves have all died, but several where they were 5 or $6 \mathrm{~mm}$. have done well after operation. If two early patients who died are omitted, all except one where PII was more than $3 \mathrm{~mm}$. have been advised to have operations; it seems that a PII of more than $5 \mathrm{~mm}$. has some prognostic significance and is often an indication for valvotomy.

$P$ Waves and the Pressure in the Right Atrium. . The larger $P$ waves are all associated with a high right atrial pressure and, therefore, presumably with atrial hypertrophy as suggested by Brown (1939) and by Wood and Selzer (1939). They were correlated as follows:

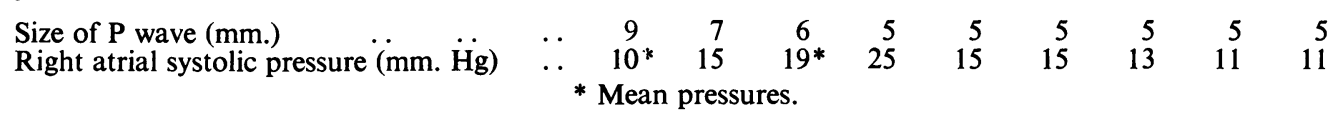

Of the 15 with the largest $\mathbf{P}$ waves several were early cases, so we have measurements of the atrial pressure in 9 only. It is clear that these are high pressures, but the parallel is not exact and it is possible to have systolic pressures of 17,16 , and $13 \mathrm{~mm}$. with $P$ waves that are only $3 \mathrm{~mm}$.

\section{The Pressure in the Right Atrium}

The atrial systolic pressure averaged $14 \mathrm{~mm}$. $\mathrm{Hg}$ in the cyanotic cases, and in the acyanotic, $9.5 \mathrm{~mm}$. in those who have had valvotomy and $6.5 \mathrm{~mm}$. in those who have not. Although it is generally higher when there is cyanosis, it is sometimes as high when there is no cyanosis, and then probably the foramen ovale is firmly sealed. Where only mean pressures were available they have been included in Table VI.

Some of the highest pressure were found in early patients with severe symptoms, and this might be expected for there is some correlation between the pressures in the right atrium and in the right ventricle. Deuchar (personal communication) has kindly given me a chart relating these in patients with simple pulmonary stenosis that he has catheterized, and the pressure in the right atrium arises from about 5 to about $10 \mathrm{~mm}$. as the pressure in the right ventricle rises from about 50 to between 
110 and $140 \mathrm{~mm} . \mathrm{Hg}$, but there is a wide scatter and some cases show a much higher pressure than these average figures.

Abrahams and Wood (1951) found that there was often an $a$ wave of $5 \mathrm{~mm}$. in moderate cases with a right ventricular pressure of from 50 to $100 \mathrm{~mm}$., and a giant $a$ wave in severe cases when the right atrial systolic pressure was about $10-15 \mathrm{~mm}$. and the ventricular pressure from 100 to $175 \mathrm{~mm}$. These pressures were measured above the sternal angle so should be increased somewhat to compare with ours which are measured from the level of the mid-axillary line. A giant $a$ wave means such high pressure on the right side of the heart that operation is probably indicated, but the dividing line between large and moderate waves may be difficult and the ease with which $a$ waves can be seen varies with the anatomy of the neck.

TABLE VI

Right Atrial Pressures in Simple Pulmonary Stenosis

Right atrial systolic pressures (mm. $\mathrm{Hg}$ )

\begin{tabular}{|c|c|c|c|c|c|c|c|c|c|}
\hline & & & & $0-4$ & $5-9$ & $10-14$ & $15-19$ & $\begin{array}{l}20 \text { and } \\
\text { above }\end{array}$ & Average \\
\hline \multicolumn{4}{|c|}{$\begin{array}{l}\text { Cyanotic } \\
\text { Acyanotic with operation } \\
\text { Acyanotic without operation }\end{array}$} & $\begin{array}{l}0 \\
2 \\
3\end{array}$ & $\begin{array}{l}3 \\
9 \\
8\end{array}$ & $\begin{array}{l}3 \\
6 \\
2\end{array}$ & $\begin{array}{l}3 \\
3 \\
0\end{array}$ & $\begin{array}{l}2 \\
0 \\
0\end{array}$ & $\begin{array}{l}14 \\
9 \cdot 5 \\
6 \cdot 6\end{array}$ \\
\hline Total & . & . & . & 5 & 20 & 11 & 6 & 2 & \\
\hline \multicolumn{10}{|c|}{ Mean pressures only } \\
\hline $\begin{array}{l}\text { Cyanotic } \\
\text { Acyanotic }\end{array}$ & $\begin{array}{l}\ldots \\
.\end{array}$ & $\begin{array}{l}\ldots \\
\ldots\end{array}$ & $\begin{array}{l}. . \\
\ldots\end{array}$ & $\begin{array}{l}4 \\
6\end{array}$ & $\begin{array}{l}5 \\
1\end{array}$ & $\begin{array}{l}2 \\
0\end{array}$ & $\begin{array}{l}1 \\
1\end{array}$ & - & $\begin{array}{l}7 \\
4\end{array}$ \\
\hline
\end{tabular}

The Passage of the Catheter through the Atrial Septum. The high pressures, when there is central cyanosis, suggest that it is due to a right-to-left inter-atrial shunt, but single cases are more decisive. The 24 with cyanosis, where the pertinent figures are available, have been divided into 10 with severe cyanosis, where the arterial $\mathrm{O}_{2}$ saturation was generally under 70 per cent, and 14 with slighter cyanosis where it was generally over 84 per cent. The catheter entered the left atrium in 7 of the 10 with severe cyanosis; the mean pressure was higher in the right in two, 15 and 4 , and 3 and $1 \mathrm{~mm}$. respectively; but was recorded as the same in three with mean pressures of 9,3 , and $1 \mathrm{~mm}$.; and in the remaining two, no pressure record was obtained from the left atrium. The catheter passed through the atrial septum in only 4 of the 14 with less severe cyanosis, and the respective systolic pressures were 20 and 12 in the first, 7 and 5 in the second, mean pressures of 10 on both sides in the third, and no pressure reading was obtained from the left atrium in the fourth.

There were, therefore, 8 cases where the catheter passed from the right to the left atrium and the pressure was measured in both atria; it was never higher in the left atrium, and was higher in the right atrium in four and was recorded as the same in four; in these four, only a mean pressure was available, and it may have been higher at some stage of the cardiac cycle for a very small pressure gradient seems enough to produce a right-to-left inter-atrial shunt.

Even in those who were acyanotic at rest the catheter sometimes passed from the right to the left atrium ( 4 of 40 cases), though much less often than in the cyanotic (11 of 24 cases). In one of these they were 5 and 6 respectively, and in the second 4 and $6 \mathrm{~mm}$. (mean) respectively, so that these two could not have a right-to-left inter-atrial shunt even though there was a potential opening. They may well be patients who could develop cyanosis later, but in one we hope this possibility has been prevented by a successful valvotomy. In the remaining two the pressure in the left atrium was not recorded. 


\section{The Pressure in the Right Ventricle}

One of the most surprising findings in these patients is the high right ventricular pressure, which is often over $100 \mathrm{~mm}$. $\mathrm{Hg}$ in both groups, and generally so in the cyanotic group, without any increase of the pulmonary arterial pressure, which is normal or low. Even allowing for some lability of the pressure these great increases readily explain the severe right ventricular strain and the serious prognosis in some cases.

It is important to emphasize that these patients who have been catheterized are not representative. They were often chosen because their symptoms or cardiographic pattern pointed to the need for operation, and the two with the highest pressures (238 and 240) were sent to Mr. Brock from New York and from Paris, probably because their pressures were unusually high.

The ranges of the right ventricular systolic pressures in the cyanotic and acyanotic cases are much the same except that several acyanotic and few, if any, cyanotic (see Table VII) have pressures less

TABLE VII

Range of Right Ventricular Systolic Pressure in Simple Pulmonary Stenosis

Right ventricular systolic pressure $(\mathrm{mm} . \mathrm{Hg})$

\begin{tabular}{|c|c|c|c|c|c|c|c|c|c|}
\hline & & $\begin{array}{l}35 \\
\text { to } \\
59\end{array}$ & $\begin{array}{l}60 \\
\text { to } \\
79\end{array}$ & $\begin{array}{l}80 \\
\text { to } \\
99\end{array}$ & $\begin{array}{c}100 \\
\text { to } \\
119\end{array}$ & $\begin{array}{c}120 \\
\text { to } \\
139\end{array}$ & $\begin{array}{c}140 \\
\text { to } \\
159\end{array}$ & $\begin{array}{c}160 \\
\text { to } \\
179\end{array}$ & $\begin{array}{l}180 \\
\text { and } \\
\text { over }\end{array}$ \\
\hline $\begin{array}{l}\text { Cyanotic (26) } \\
\text { Acyanotic (41) }\end{array}$ & $\begin{array}{ll}. & . \\
. & . .\end{array}$ & $\begin{array}{l}0 \\
5\end{array}$ & $1^{*}$ & $\begin{array}{l}1 \\
3\end{array}$ & $\begin{array}{l}9 \\
8\end{array}$ & $\begin{array}{l}4 \\
6\end{array}$ & $\begin{array}{l}4 \\
8\end{array}$ & $\begin{array}{l}3 \\
6\end{array}$ & $\begin{array}{l}4 \\
2\end{array}$ \\
\hline
\end{tabular}

* Pressure was recorded only at operation.

than 80. All but two of the acyanotic patients with a pressure over 100 , and only one of those with it less than this, have had valvotomy. Many in the upper ranges are presumably patients who could not develop central cyanosis because the foramen ovale is sealed. For this comparison, in Table VII, figures for the systolic pressures have been interpolated from the mean pressures in nine cyanotic and two acyanotic cases; to make sure that these are not exaggerated the systolic pressure has been taken as double the mean pressure and, in fact, is much more than this whenever there are records of both. Most of these interpolated figures fall in the lower range so that the systolic pressures for the cyanotic cases should be higher.

In the cyanotic group the systolic pressure was generally between 110 and 170, but it was 181 in a girl of 7, who had only become cyanotic since she was 5; 175 in a boy aged 10, who had been disabled since infancy; 238 in a girl, and 240 in a young man, who were becoming very disabled. There was only one patient where the mean pressure was under $50 \mathrm{~mm}$. $(45 \mathrm{~mm}$.) and one where the systolic pressure was under $100 \mathrm{~mm}$., and in her it was found to be $65 \mathrm{~mm}$., but it was measured at operation when it is often much lower than at catheterization.

In the acyanotic group the right ventricular systolic pressures were generally between 60 and 170 . In one boy, aged 12, with few symptoms it was 180 ; in one young man, leading an active life as an undergraduate, it was 170; and this level was also reached by two girls, aged 6 and 9, who had more severe symptoms. Here there is a striking contrast between those who have, and those who have not, had operations. The latter included the ten with the lowest pressures, under 90, and only two who were in the range of 110 to 130 ; while in all but one who have had operations, it has been over $100 \mathrm{~mm}$. So far, no patient with a lower pressure has shown signs of becoming worse, so there has been no question of recatheterization or of advising operation. Soulié et al. (1953) and others have pointed out how well the milder cases do without operation. 


\section{CARDIAC OUTPUT}

In spite of the severe pulmonary stenosis many of these patients had a normal pulmonary flow, but this is maintained only by the high pressure in the right ventricle and at the risk of right ventricular strain.

Cyanotic Group. The cardiac index was nearly always normal or reduced and averaged 2.7 litres/sq. $\mathrm{m}$./minute. In 6 of the 20 with available information it was within the normal limits of $3.0-4.0$ (generally $3 \cdot 0-3 \cdot 5$ ) litres $/ \mathrm{sq} . \mathrm{m}$. $/ \mathrm{min}$. and 3 of these were very disabled patients where we should have expected it to be lower. In one it was higher than this. In the remaining 13 it was reduced (average 2.2 litres $/ \mathrm{sq} . \mathrm{m}$. $/ \mathrm{min}$.) but there were only three where it was under 2.0 litres. The pulmonary flow was, of course, reduced because of the right-to-left shunt (see page 275).

Acyanotic Group. Less than a quarter of these had a reduced flow. In 10 it was above 4.5 litres/sq. m./min., which shows that their condition was not basal at the time, but that they could increase their output. Four of these have had valvotomy: the fact that their cardiac outputs were somewhat raised might seem to show that they did not need it, but right ventricular systolic pressures between 120 and 155 were thought to be a more decisive factor; none of them were much disabled. The other 6 had had pressures between 55 and 88 and none had severe symptoms. There were 20 patients where the cardiac index fell within the normal range, including 13 of those who had operations and some others with moderate disability.

There were only 9 where it was below 3 litres/sq. m./min. All but one of these have had valvotomy, although it was not generally used as one of the criteria for operation. The one exception had a right ventricular pressure of $120 / 0$, but as he was able to play football and had no abnormal $\mathrm{T}$ inversion, operation was not advised; two years later, however, it has been advised as some $\mathrm{T}$ inversion is appearing. In 6 patients it was round about 2 litres; most of these had enough symptoms to make operation desirable in any case, but two with cardiac indices of $2 \cdot 3$ and $2 \cdot 1$ led active lives with few symptoms and little peripheral cyanosis, one being able to climb mountains and cycle 100 miles without difficulty, and the other being able to dance after a normal working day. In both the right ventricular systolic pressure was over 140 and there was $T$ inversion across to V4, so that valvotomy seemed urgent in spite of the slight symptoms.

It seems clear from these figures that the cardiac output becomes reduced only at a late stage. This, incidentally, makes it less easy to explain the frequency of peripheral cyanosis, and suggests that there must be some reflex peripheral vaso-constriction and local stasis rather than a general reduction of the flow. Such a mechanism for reducing the peripheral blood flow might develop because there is an inadequate increase of cardiac output with exercise.

\section{Pathological Anatomy}

The most important feature is the pulmonary stenosis, almost always with dilatation of the pulmonary trunk. There are 13 hearts available, including the 7 described by Allanby and Campbell in 1949. In all these, and in nearly all the reported cases, the stenosis is at the pulmonary valve. Infundibular stenosis with a closed ventricular septum has been described, and we have seen two examples (one confirmed by operation and one by cardiac catheterization) but none proved by necropsy. Although infundibular stenosis is rare, the massive muscle of the right ventricle may cause some obstruction to its outflow tract: this may sometimes show on angiocardiography. Very rarely, the stenosis may be in the pulmonary trunk (Peacock, 1866, and Kreutzer 1953).

The valvular stenosis generally has the same form, and this was so in all these 13 cases-a small central aperture in the conical or dome-like diaphragm that projects into the pulmonary trunk (Fig. 11). It was often no more than 2 or $3 \mathrm{~mm}$. in diameter during life. This diaphragm is formed of the fused cusps - the normal three cusps in all our cases. They were often much thickened and sometimes the demarcation between them was obscured; but none was calcified or grossly deformed in shape or had an eccentric opening, as may happen in congenital aortic stenosis (Campbell and Kauntze, 1953). 
FIG. 11.-A magnified photo of the pulmonary valve from above showing the fused diaphragm with a small central opening that is almost hidden by nodular development round it, though this is unusual. Case 12 (O328). Compare Fig. 14 and 15 of Allanby and Campbell (1949) which give more usual examples.

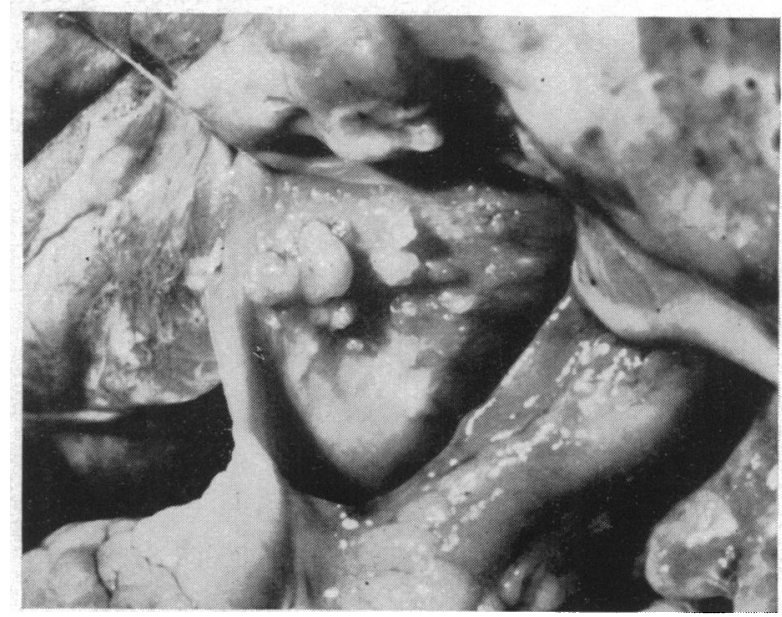

The pulmonary trunk was generally thin-walled and always dilated, sometimes greatly so, and this often extended to the left branch and sometimes to the right, but not to the smaller branches.

The rest of the heart was generally normal except for the gross right ventricular preponderance and the atrial septum. The right atrium was always large and often twice the size of the left, but was otherwise normal except for the inter-atrial communication. The tricuspid valve was normal except that the ring was generally dilated: this was noticeably so in Case 10 where the cusps were thickened and there had been clinical signs of tricuspid regurgitation for two years at least before his death. There were old nodular vegetations in the tricuspid valve in Cases 4 and 9 but nothing to suggest recent infection.

The heart was on the average double the expected weight, the increase ranging between 150 and 300 per cent. As this increase was mainly due to the right ventricle it shows how much it was hypertrophied. Its wall was always nearly as thick as and often much thicker than that of the left ventricle $(13 \mathrm{~mm}$. against $11 \mathrm{~mm}$. on the average; see Table VIII); sections of the muscle showed advanced and widespread but localized fibrotic changes. The infundibulum was normal, though there was often some endocardial thickening. The ventricular septum was closed.

TABLE VIII

Some Anatomical Data about the Heart in Simple Pulmonary Stenosis

\begin{tabular}{|c|c|c|c|c|c|c|c|}
\hline \multirow{2}{*}{ Case No. } & \multirow{2}{*}{$\begin{array}{l}\text { Diameter of } \\
\text { pulmonary } \\
\text { valve orifice } \\
\text { (mm.) }\end{array}$} & \multirow{2}{*}{$\begin{array}{l}\text { Size of } \\
\text { defect in } \\
\text { atrial } \\
\text { septum } \\
\text { (mm.) }\end{array}$} & \multicolumn{2}{|c|}{$\begin{array}{l}\text { Relative thickness of } \\
\text { ventricles }\end{array}$} & \multirow{2}{*}{$\begin{array}{c}\text { Weight of } \\
\text { heart } \\
\text { (g.) }\end{array}$} & \multirow{2}{*}{$\begin{array}{c}\text { Expected } \\
\text { weight } \\
\text { (g.) }\end{array}$} & \multirow{2}{*}{$\begin{array}{c}\text { Cardio- } \\
\text { thoracic } \\
\text { ratio }\end{array}$} \\
\hline & & & $\begin{array}{l}\text { Right } \\
\text { (mm.) }\end{array}$ & $\begin{array}{l}\text { Left } \\
(\mathrm{mm} .)\end{array}$ & & & \\
\hline 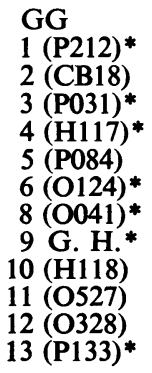 & $\begin{array}{l}\overline{3} \\
5 \\
2 \\
3 \\
3 \\
\frac{1-2 \dagger}{1-}+ \\
\frac{-}{1 \cdot 5} \\
? 1 \cdot 5 \\
2 \\
2\end{array}$ & $\begin{array}{c}\text { None } \\
\text { None } \\
3 \times 1 \\
1 \times 1 \\
7 \times 3 \\
10 \times 6 \\
11 \times 5 \\
12 \times 3 \\
16 \\
7 \times 5 \\
17 \times 4 \\
6 \times 2 \\
18 \times 12\end{array}$ & $\begin{array}{r}- \\
15 \\
17 \\
20 \\
19 \\
15 \\
9 \\
9 \\
20 \\
9 \\
9 \\
7 \\
14\end{array}$ & $\begin{array}{r}-12 \\
12 \\
14 \\
14 \\
16 \\
13 \\
8 \\
10 \\
10 \\
8 \\
15 \\
8 \\
11\end{array}$ & $\begin{array}{l}\overline{450} \\
575 \\
600 \\
475 \\
500 \\
540 \\
370 \\
502 \\
300 \\
120 \\
500 \\
420\end{array}$ & $\begin{array}{c}\overline{195} \\
400 \\
363 \\
351 \\
282 \\
243 \\
125-150 \\
260-320 \\
95-88 \\
34-40 \\
150 \\
240-290\end{array}$ & $\begin{array}{l}- \\
70 \\
55 \\
64 \\
54 \\
52 \\
56 \\
63 \\
53 \\
80 \\
61 \\
70 \\
62\end{array}$ \\
\hline
\end{tabular}

* Died after operation.

$\dagger$ Valvotomy had been performed so the measurements are uncertain. 
The systemic and pulmonary veins drained normally into the right and left atria. The left side of the heart was normal except for minor changes. The mitral cusps were rather thickened in three cases but never fused, and there was little or no thickening of the chordæ tendineæ. The ring was greatly dilated in Case 10, who had the largest heart and an unexplained apical diastolic murmur.

The aortic valve was always normal except that it was bicuspid in Case 12. The aorta was normal except that in Case 9 it was slightly narrowed at the point of origin of the ductus arteriosus. The ductus arteriosus was closed in all except Case 11, where it was just patent to a probe. No notes were made about the bronchial arteries in Cases 9,11 , and 12 , but they were not specially large in Cases 8, 10, and 13.

Apart from the signs of congestive failure in most patients who died, the only common abnormality was the cardiac cirrhosis of the liver (Fig. 17). This is sometimes extreme, especially if the patient had been incapacitated for long. The histological picture was discussed by Allanby and Campbell (1949) and we have nothing to add, except to stress its frequency in simple pulmonary stenosis. This is not widely realized, e.g. an excellent paper on cardiac cirrhosis by Moschowitz (1952) does not refer to pulmonary stenosis as a cause. We agree with him that the raised pressure in the hepatic veins is probably an important cause.

\section{The Atrial Septum and the Right-To-Left Shunt}

The importance of a foramen ovale that is not sealed and so allows a right-to-left shunt is well recognized. Selzer and Carnes (1953) have reviewed all the reported cases with necropsies and conclude that when there is central cyanosis there is always an opening in the atrial septum. They discuss the apparent exceptions, including Case 2 of Allanby and Campbell (1949).

We have, therefore, examined the foramen ovale with particular care. The original necropsy report of Case 12 stated that there was no communication between the right and left sides of the heart, so this seemed another exception, but re-examination of the heart showed a typical foramen ovale that was covered by a valve flap but not sealed. The opening was missed at first because it was only in one direction that the probe passed freely through the foramen ovale to the left atrium.

Allanby and Campbell (1949) were surprised at the anomalous findings in their Case 2 with cyanosis, polycythæmia, and clubbing but with a closed atrial septum. Our experience with the heart of Case 12 and the paper of Selzer and Carnes (1953) led us to re-examine this heart, and we regret that our original account was incorrect. The fossa ovalis, $36 \times 28 \mathrm{~mm}$., was translucent, and from the left atrial aspect showed a free edge from the main septum (annulus ovalis) slightly overlapping this. After some minutes' examination with a probe I still thought there was no opening: most parts of this rim were completely sealed about $2 \mathrm{~mm}$. under the free edge, but there was an opening at the junction of the lower and middle thirds, through which a flat probe $3 \mathrm{~mm}$. broad passed easily (Fig. 12). From the right atrial aspect the opening was hidden by the overlapping edge, but it was easy to pass a probe from this side also. The gentle use of a blunt probe could not, I feel sure, have made this opening, so there was, in fact, an anatomical basis for a rightto-left shunt and for his renal infarct-a paradoxical embolism from the thrombus in the capacious right atrium.

With this experience, and the similar case reported by Eakin and Abbott (1933), great care should be taken in examining the foramen ovale and it seems that central cyanosis always indicates an opening in the atrial septum-points where we are now in complete agreement with Selzer and Carnes (1953). They conclude that the opening is always a patent foramen ovale, but this is not so. The atrial septum will be described briefly as there seems to be some doubt about the varieties of atrial septal defect or at least about the use of this term and of " patent foramen ovale."

The Nature of Atrial Septal Defects. (1) If the septum primum fails to develop properly so that the ostium primum remains open, there will be a defect of the lower (caudal) part of the atrial septum. Such defects, which are easy to recognize, are sometimes found with defects of the A-V valves; they are not uncommon in mongols, but were not found in this series. 


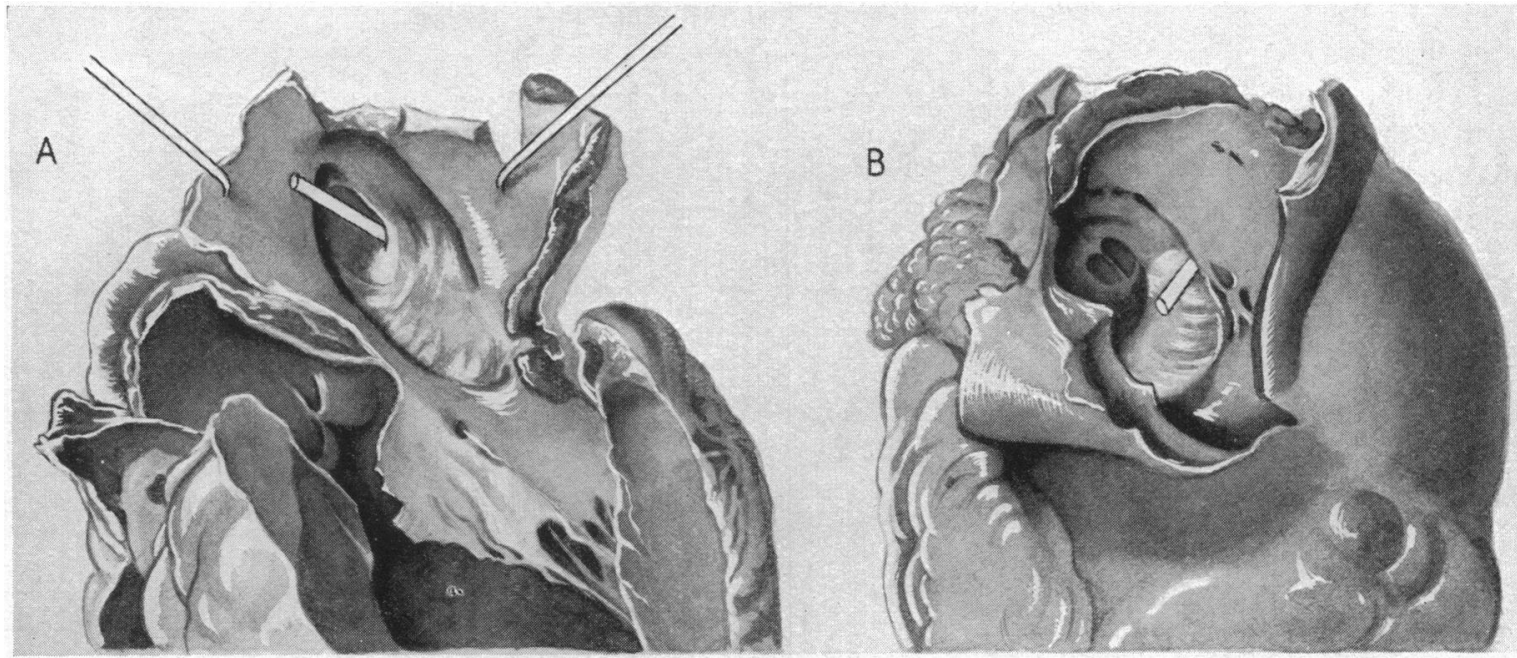

FIG. 12.-The unsealed foramen ovale in Case 2. (A) From the left atrium, showing a probe passing through the foramen ovale near the middle of the fossa ovale. (B) From the right atrium, showing the same probe. A large thrombus lies under the wall on the right of the drawing. Fig. 21 of Allanby and Campbell (1949) shows this atrium and the thrombus but we failed to realize that the foramen ovale was not sealed.

(2) If the septum secundum does not develop at all, there will be a persistent ostium secundum at the upper (cranial) end of the septum. Defects at this site are not common except when most of the septum is absent (Case 11).

(3) If the septum secundum fails to grow far enough to reach the remnant of the septum primum below, there will be a true atrial septal defect about the middle of the septum and this is the commonest form.

(4) If the septa fuse normally but the valve flap covering the foramen ovale (a remnant of the septum primum) is absent, there is an opening that may be hard to distinguish from (3). This is sometimes referred to as a "widely patent foramen ovale"- a term that is better avoided because

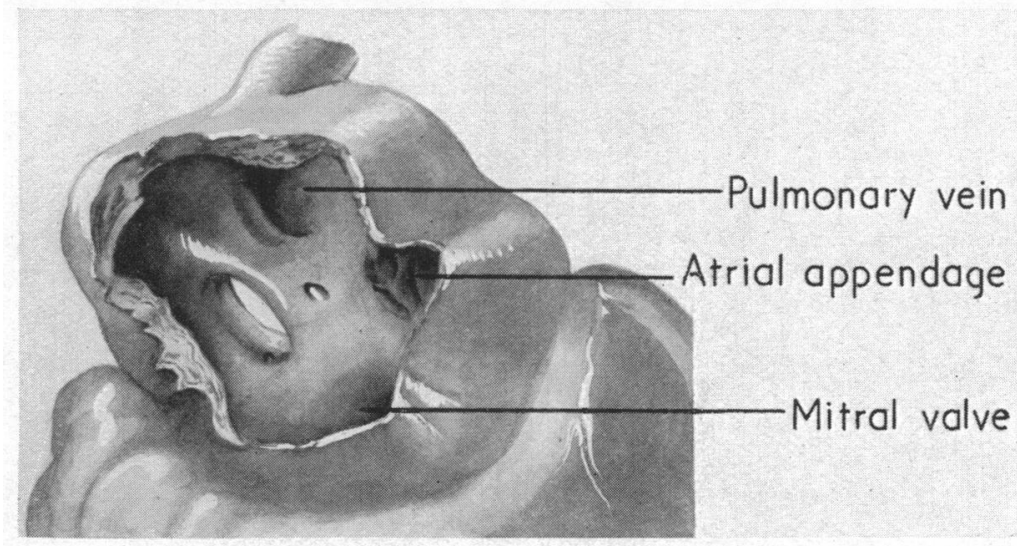

FIG. 13.-A small atrial septal defect in a patient with simple pulmonary stenosis, seen from the left atrium. The opening is of moderate size and is at the site of the foramen ovale; it seems unlikely that it was ever covered by a valve flap, unless in the course of years this can become worn away. Case 8. 


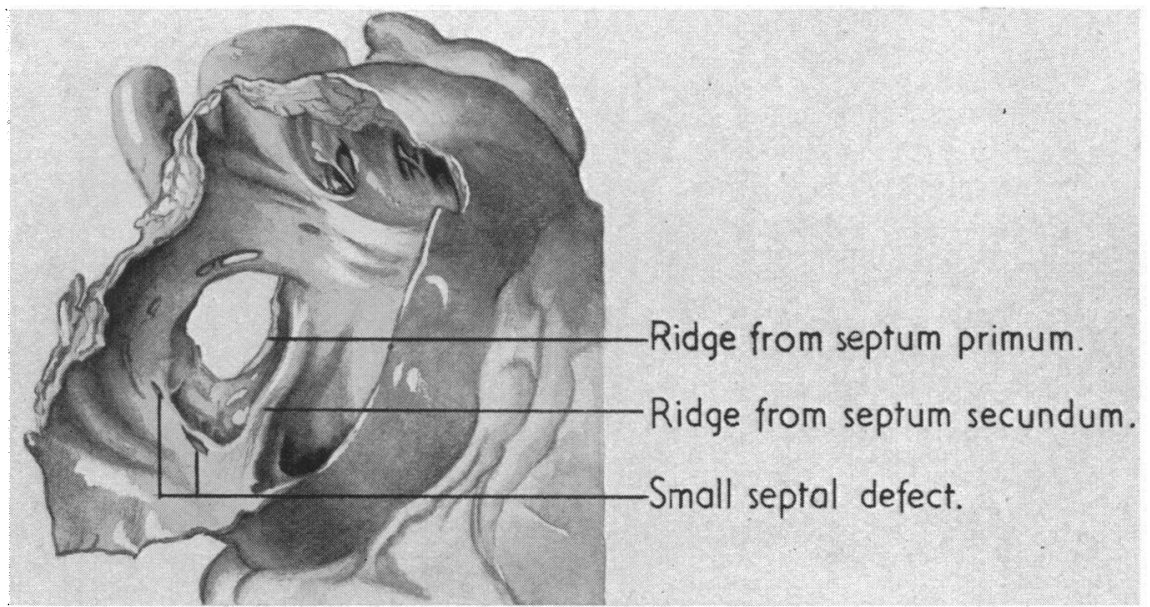

Fig. 14.-A large atrial septal defect, $18 \times 12 \mathrm{~mm}$., viewed from the left atrium, the wall of which has been cut away. The two ridges seemed to be remnants respectively of the septum primum and of the septum secundum fused with the sinus septum. Case 13.

if the valve flap is not large enough to cover the opening the septum has not developed normally and there is an atrial septal defect, albeit a small one.

(5) If the septum secundum fuses with the remnants of the septum primum normally and the foramen ovale is completely covered with a valve flap but not anatomically sealed, blood cannot flow from left to right but can flow from right to left if the pressure on the right side is high enough. This is generally called a patent foramen ovale, but to avoid confusion with (4) would be better called an unsealed foramen ovale.

The Atrial Septum in our Cases. In two of these (Cases 1 and G.G.) the atrial septum was completely closed, but in all the others who were cyanotic, a right-to-left shunt through the atrial septum was possible. In three (Cases 2, 3, and 12) the foramen ovale was perfectly formed and the unsealed valve flap allowed a right-to-left shunt only (Fig. 12). In two (Cases 4 and 5) the foramen ovale was normally formed but the opening was larger and it was less certain that the valve flap had ever covered it completely. In the remaining six there was an atrial septal defect and the septum was not normally formed though in four (Cases 6, 8, 9, and 10) it might perhaps have been called a widely patent foramen ovale (Fig. 13). In the last two, however, there was a large defect of the atrial septum, the septum secundum being poorly developed in one (Fig. 14, Case 13) and almost absent in the others (Fig. 15, Case 11).

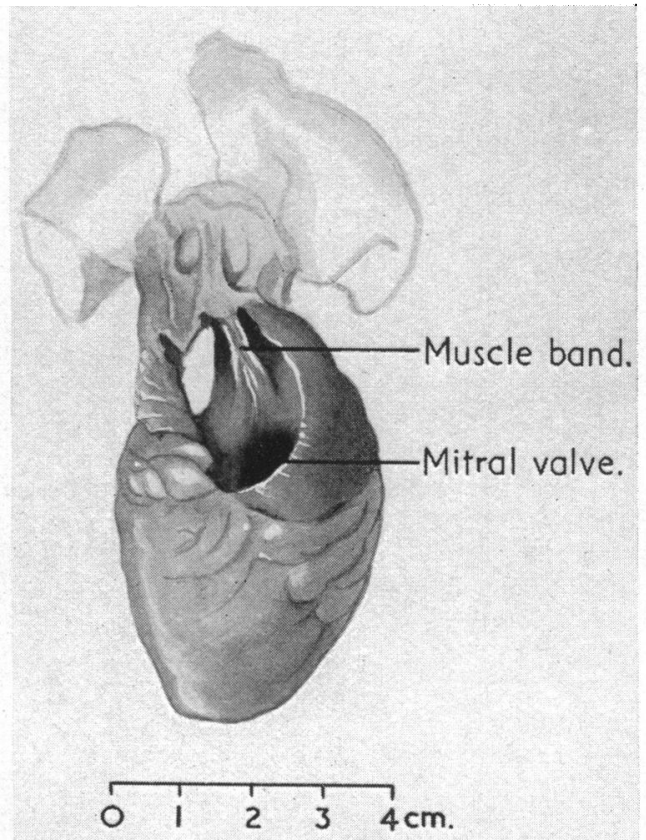

FIG. 15.-A large atrial septal defect, $17 \times 4 \mathrm{~mm}$., where there seemed to be little, if any, development of the septum secundum. There was no trace of any valve flap. The heart seen from the left side with the left atrium opened. Case 11. 


\section{Notes OF CASES WITH NeCROPSY}

The following points were common to all the patients and are recapitulated here to save repetition. None gave a history of squatting except Case 12. Unless otherwise stated, there was a systolic thrill in the pulmonary area. No diastolic murmur was heard except in Case 10 toward the apex.

On radioscopy the enlargement of the heart was mainly due to the right ventricle, and the pulmonary trunk and the left pulmonary artery were dilated in varying degree. The aortic arch was left-sided. There was right ventricular preponderance in the electrocardiogram. The common features of the necropsy have been described.

Case G.G. and Cases 1-6 have already been fully reported (Allanby and Campbell, 1949; their Case 7 is still well).

Case 8 (O041). This girl, aged 8 years, had always been breathless, but could sometimes walk a mile slowly. No cyanosis was observed till she was 4 , and neither this nor the clubbing, nor the polycythæmia (hæmoglobin 120\%) were severe when she was first seen.

The heart was greatly enlarged, c.t.r. 57 (m.t.d. 12/21 cm.). A harsh systolic murmur was well heard in the pulmonary area and the second sound was normal. No systolic thrill was felt. The blood pressure was $105 / 65$. The cardiogram showed a pointed PII of $7 \mathrm{~mm}$. and T inversion across the chest leads to V5.

During the next year she became much worse and had sternal pain on walking a few yards. Her cyanosis and clubbing increased, the red cell count rose to 8.6 million, the hæmoglobin to 158 per cent, and her heart became still larger (c.t.r. 63). At catheterization the pulmonary artery could not be entered, but the pressure in the right atrium was $15 / 4$ and in the right ventricle 155/27 against a systemic pressure of $105 / 65 \mathrm{~mm}$. The arterial $\mathrm{O}_{2}$ saturation was only 52 per cent.

Even in the short period of waiting for pulmonary valvotomy she had two attacks of unconsciousness in which she seemed to be dead-the second just after her admission to hospital. Unfortunately, the heart stopped beating before the operation was started, though after an injection of adrenalin valvotomy was quickly performed in the vain hope that it might assist her recovery.

Necropsy. The heart weighed $370 \mathrm{~g}$. The right atrium was hypertrophied and dilated, the cavity being about twice the size of the left atrium. There was a crescentic defect measuring $12 \mathrm{~mm}$ by $3 \mathrm{~mm}$. in the upper posterior part of the atrial septum (Fig. 13). Apart from this both the septum primum and the septum secundum were normally formed.

The tricuspid valve was dilated ( 35 by $26 \mathrm{~mm}$.). The right ventricle was greatly hypertrophied. The pulmonary valve consisted of the usual diaphragm convex upwards and formed of three cusps. The valve ring was normal in size $(14 \times 14 \mathrm{~mm}$.) and the central opening had been dilated by operation but had probably been no more than 1-2 mm. The pulmonary trunk was dilated to a diameter of $20 \mathrm{~mm}$. compared with $14 \mathrm{~mm}$. for the aorta, $2 \mathrm{~mm}$. above the valve rings. The left side of the heart was normal.

The liver was enlarged and showed nutmeg changes and some degree of fibrosis. The other viscera were normal.

Case 9 (Case 19; Brock and Campbell, 1950). This girl, aged 22, was under the care of Dr. Wood. She had always been cyanosed and became more so at 12 and again at 20 ; she was always dyspnoic but could walk two miles and swim and dance till she was 16 years of age. From then she gradually became worse and could only walk 300 yards and sometimes lost consciousness.

She was intensely cyanosed with severe clubbing and polycythæmia, the red cells being $7 \cdot 3$ million, and the hæmoglobin 142 per cent. There was a harsh systolic murmur without a thrill in the pulmonary area and the second sound was pure. B.P. 110/90. Her heart was enlarged, c.t.r. 53 (m.t.d. 14.0/26.5). The cardiogram showed $\mathrm{T}$ inversion to $\mathrm{V} 3$. The arterial $\mathrm{O}_{2}$ saturation was only 50 per cent and the mean pressure in the right ventricle was $64 \mathrm{~mm}$. Hg. She did well for some days after valvotomy, but then died rather suddenly.

Necropsy (by the late Dr. Channell). The heart was enlarged and weighed $502 \mathrm{~g}$. Its surface was covered by fibrin and was slightly reddened and inflamed. The right atrium was dilated and hypertrophied. There was a rather large atrial septal defect with a diameter of $16 \mathrm{~mm}$. The tricuspid valve cusps showed some old vegetations. The right ventricle was greatly hypertrophied. The pulmonary valve showed the dome-like fusion of the cusps and the small opening was surrounded by old thickened vegetations. The pulmonary trunk was greatly dilated beyond the stenosis, the diameter being $30 \mathrm{~mm}$. compared with $14 \mathrm{~mm}$. for the aorta at the same level.

The left side of the heart was normal. There was slight narrowing of the aorta at the point of origin of the ductus arteriosus which was closed.

Case 10 (H118). This boy, 6 years old, had never walked more than 100 yards. Cyanosis had been present from birth, the fingers were clubbed, and the hæmoglobin was 120 per cent with a red cell count of 
6.5 million. He was small and thin and had a very prominent abdomen due to the large liver. The venous pulse in the neck due to a large $a$ wave had been noted for some time.

There was a harsh systolic murmur, best heard in the pulmonary area, and a diastolic thrill and murmur at the apex. The blood pressure was $80 / 60$. His cardiogram showed a large pointed PII and T inversion in leads III and from V1 to V4. The heart was very large, c.t.r. 80 (m.t.d. $14 \cdot 3 / 17 \cdot 8 \mathrm{~cm}$.).

The catheter passed from the right atrium (mean pressure $15 \mathrm{~mm}$. $\mathrm{Hg}$ ) to the left where the pressure was much lower $(4 \mathrm{~mm}$.), but could not be advanced into the right ventricle. It was, therefore, certain that he had a right-to-left inter-atrial shunt, tricuspid regurgitation, and oligæmic lung fields, but pulmonary stenosis was not then diagnosed confidently enough to advise operation, though in retrospect it seems obvious.

A year later he developed congestive failure, and died before valvotomy could be arranged, though it is doubtful if it could have reversed such advanced changes.

Necropsy. The heart was very large and weighed $300 \mathrm{~g}$. The thin-walled right atrium was greatly dilated and would admit a small fist. An oval defect of the atrial septum, $5 \times 7 \mathrm{~mm}$. across, with a thickened margin, was uncovered by any valve flap; it was slightly eccentric in a rather large fossa ovalis (Fig. 16). The tricuspid cusps were thickened and the ring was $10 \mathrm{~cm}$. in circumference. The right ventricle was much hypertrophied with stout papillary muscles. On section, the muscle showed fairly diffuse fibrosis.

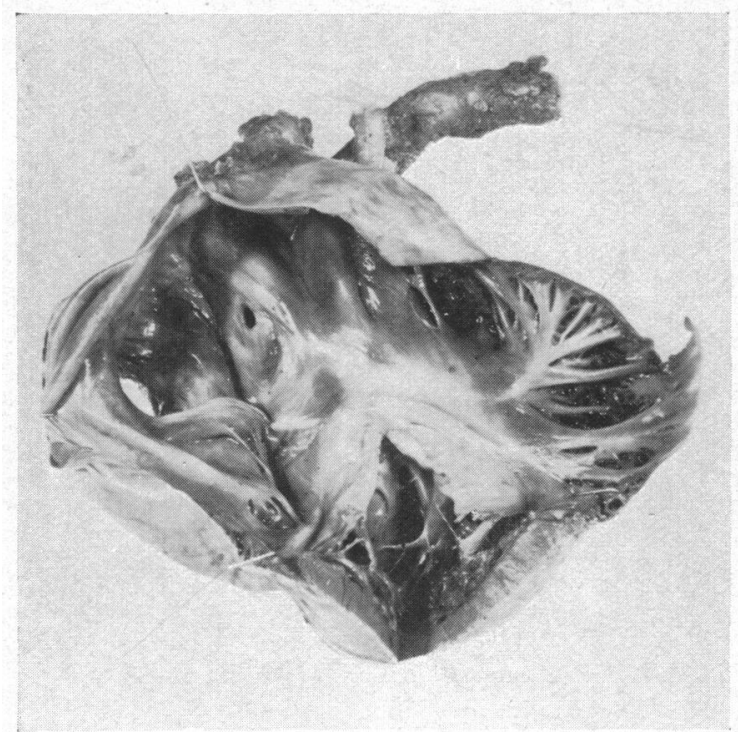

A

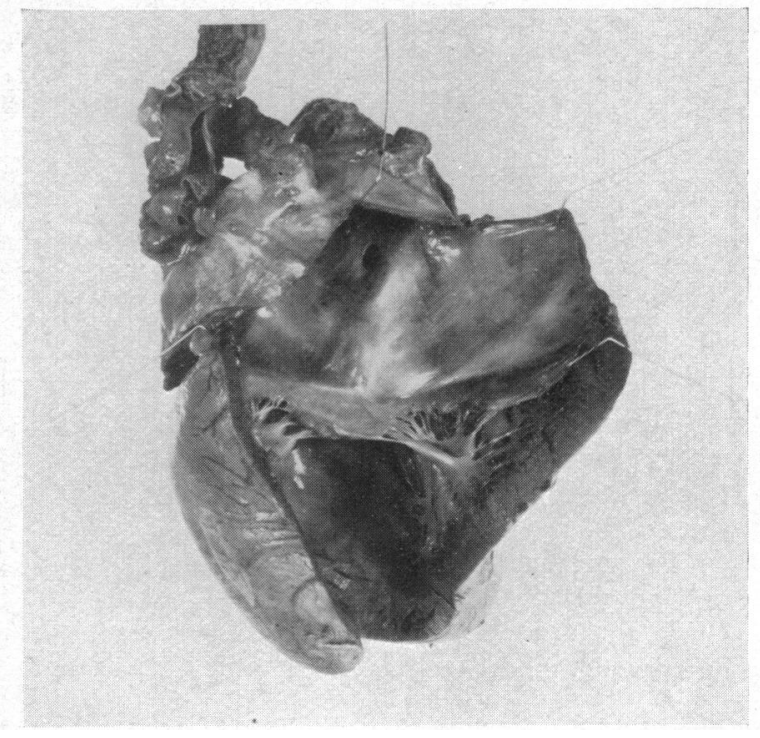

B

FIG. 16.-The heart from Case 10 showing an atrial septal defect that measured $5 \times 7 \mathrm{~mm}$. and had no trace of a valve flap. (A) The hypertrophied right ventricle and the greatly dilated right atrium with the septal defect in the centre. (B) The small left ventricle and the left atrium showing the septal defect without any covering valve flap.

The pulmonary valve showed fusion of the three cusps to form a dome with a central opening that admitted a probe of $1.5 \mathrm{~mm}$. diameter. The pulmonary trunk was greatly dilated $(18 \mathrm{~mm}$. in diameter compared with $14 \mathrm{~mm}$. for the aorta); the left branch was $13 \mathrm{~mm}$. across and the right only $7 \mathrm{~mm}$. The left side of the heart was normal except that the mitral ring was dilated and $9 \mathrm{~cm}$. in circumference.

The liver was large and weighed $740 \mathrm{~g}$. Its surface was irregularly nodular and showed cardiac cirrhosis (Fig. 17). On section there was much fatty change and some increase of fibrous tissue.

Case 11 (O527). This girl, 10 months old, was short of breath even with feeding, and cyanosis had been present from birth. Early clubbing of the fingers was already apparent. She had had two attacks of severe dyspnœa and cyanosis after crying in which she became limp and semi-conscious.

There was a harsh systolic murmur heard all over the left side but no thrill was felt; the pulmonary second sound was diminished. The heart was large, c.t.r. 61 (m.t.d. $7 \cdot 5 / 12 \cdot 2 \mathrm{~cm}$.) and the lungs were very oligæmic. The cardiogram showed a large pointed PII of $5 \mathrm{~mm}$., and the T waves were inverted in lead III and slightly biphasic with a late-rising peak in V1 to V5. The hæmoglobin was 98 per cent. During the next month there were four more severe attacks of cyanosis and unconsciousness and she died in one such attack on the day of admission. 


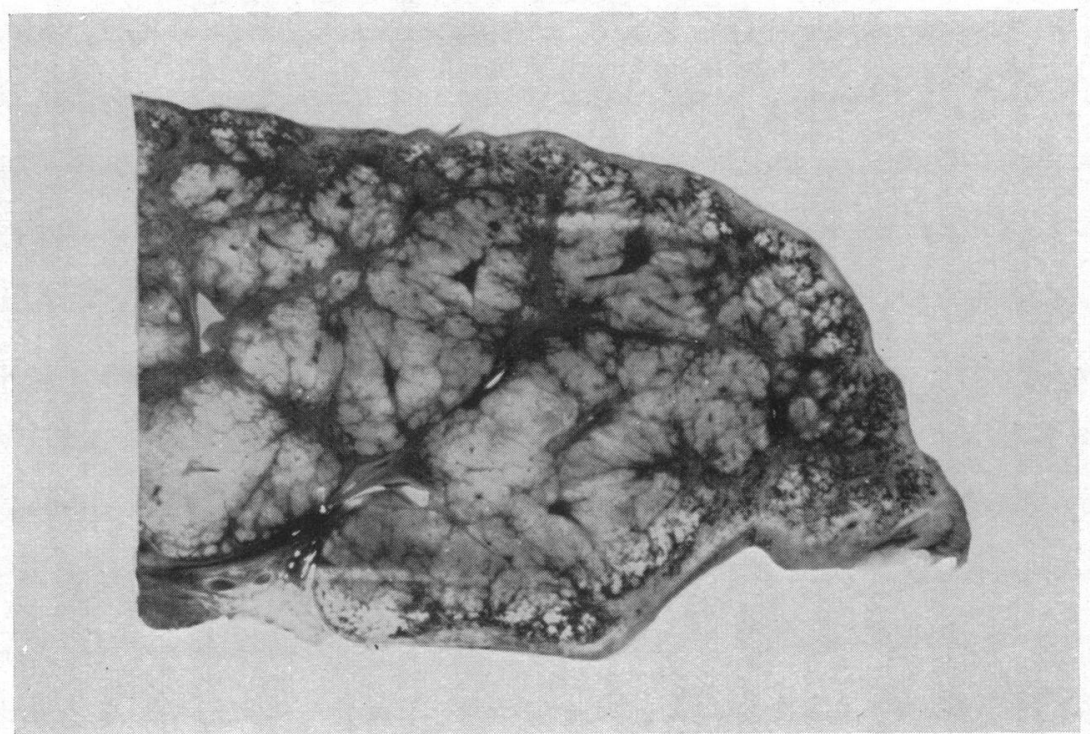

FIG. 17.-Section of the liver showing cardiac cirrhosis. The normal pattern is replaced by large and small pale areas of regenerating parenchyma, separated by broad bands of congested fibrous tissue. The surface is nodular and the capsule thickened. About two-thirds of natural size. Case 10.

Necropsy. The heart weighed $120 \mathrm{~g}$. The right atrium was much larger than the left. In the atrial septum there was a large oval defect, measuring $17 \times 4 \mathrm{~mm}$., with its long axis lying almost vertically (Fig. 15); it lay high up and rather posteriorly. There seemed to have been no development of the septum secundum.

The right ventricle was hypertrophied. There was a severe valvular stenosis and the opening would only admit a probe. It consisted of three cusps and had the usual form, a nipple-like projection extending $4 \mathrm{~mm}$. into the pulmonary trunk. There was a suggestion of an infundibular chamber about $12 \mathrm{~mm}$. long, but no stenosis at its ventricular end. The pulmonary trunk $(6 \mathrm{~mm}$. in diameter) was less dilated than usual.

The left side of the heart was normal. A small patent ductus arteriosus 2 or $3 \mathrm{~mm}$. long would just admit a fine probe.

The liver was congested and the pylorous was slightly hypertrophied.

Case 12 (0328). This girl, aged 12 years, was always rather breathless, but little more, till she was 8 years old, after which her cyanosis and disability gradually became more evident. She had not been to school for two years but could walk half a mile slowly. She had squatted for four years. She was cyanosed at rest, even on a day when her father said her blueness was less than usual; it was often deep enough to be remarked on by strangers. The hæmoglobin was 111 per cent, but the clubbing of the fingers was only slight.

There was a widely distributed systolic murmur, maximal in the pulmonary area, a systolic thrill, and a diminished pulmonary second sound; the blood pressure was 110/70. The heart was very large, c.t.r. 64 (m.t.d. 12.5/19.5 cm.) (Fig. 4A), and the lungs were very oligæmic. The cardiogram showed T deeply inverted in leads II and III and across the chest leads from V1 to V4.

Six months later, catheterization confirmed severe pulmonary stenosis, the pressure being $135 / 8$ in the right ventricle and $31 / 10 \mathrm{~mm} . \mathrm{Hg}$ in the pulmonary trunk. The arterial $\mathrm{O}_{2}$ saturation was 94 per cent and both the pulmonary and systemic flows were reduced, 1.9 instead or 3 litres a minute. The red cell count had fallen to 4.6 million and the hæmoglobin to 88 per cent, and lying in bed in the ward she did not seem cyanosed. Operation was strongly advised, but this was refused by her parents.

A year later she could only walk 100 yards, and was more cyanosed, with a still larger heart (c.t.r. 70), and even more right ventricular strain, the T inversion reaching to V6 instead of to V4. Her parents were now anxious for an operation, but after ten days in hospital, while an attempt was being made to improve her condition, she felt unwell with tightness across the chest, and died suddenly a few hours later. 
Necropsy. The heart was very large, weighing $500 \mathrm{~g}$. The right atrium was twice the size of the left but otherwise normal. From the left side the foramen ovale was covered by a valve flap. If a flat probe was passed into this vertically downwards or at all anteriorly, the foramen ovale seemed sealed, but if it was sloped rather posteriorly it passed quite easily into the right atrium. Looked at from the right, the opening was rather more obvious, and a round probe could pass through without any obstruction. The opening was no more than $6 \times 2 \mathrm{~mm}$., but this was larger than the pulmonary opening which had allowed the passage of enough blood to support life.

The right ventricle was greatly hypertrophied. There was a severe stenosis of the pulmonary valve, the cusps being fused with a central opening, $2 \mathrm{~mm}$. in diameter (Fig. 11). The pulmonary trunk was dilated (diameter $13 \mathrm{~mm} ., 10 \mathrm{~mm}$. above the valve) and the right lateral border was almost aneurysmal and its wall was covered by pale, firm, well-organized thrombus, the position suggesting it was formed by the jet of blood forced through the pulmonary valve.

The left side of the heart was normal, except that the aortic valve was bicuspid; it seemed, however, to be functioning normally.

The liver was enlarged $(1300 \mathrm{~g}$.) and showed severe passive congestion and nutmeg changes. On section, a large part of the parenchyma were replaced by dilated capillaries.

Case 13 (P133). This French girl, aged 19, was known to have a murmur from three months. When she was 4 , she was regularly cyanotic, but got on well and could walk two miles until she was 7 , when she began to lose a little ground; from 15 onwards she began to walk less and to find stairs difficult and became more cyanotic, with progressive clubbing of her fingers. When 17 , she went to Baltimore for a subclavianpulmonary anastomosis, which produced some temporary improvement but never up to her best previously.

She was seen in 1950, when she was 19, as Dr. Helen Taussig had suggested pulmonary valvotomy. She could walk very little and was deeply cyanosed. The liver was enlarged and pulsating and there was slight œdema of the ankles. There was a harsh rasping systolic and a softer thrill in the pulmonary area with a diminished second sound; and further out the continuous murmur of the anastomosis. The heart was enlarged, c.t.r. 62 (m.t.d. 14.5/23.2 cm.; two years earlier it had been 58). The cardiogram showed $\mathrm{T}$ inversion from V1 to V4, and a large pointed PII, $9 \mathrm{~mm}$. high - changes that had been present for at least three years. The red count was 7.5 million (as in 1947) and the hæmoglobin 154 per cent $(148 \%$ in 1947).

Angiocardiography confirmed a shunt from the right to the left atrium, and suggested severe pulmonary stenosis. Catheterization was repeated: the mean right ventricular pressure was $53 \mathrm{~mm} . \mathrm{Hg}$, but the pulmonary trunk could not be entered. The arterial $\mathrm{O}_{2}$ saturation was 69 per cent. The catheter passed readily to the left atrium and the atrial septal defect seemed large; the effective pulmonary blood flow was only 1.7 litres/min. with a right-to-left shunt of 3.4 litres $/ \mathrm{min}$.

At operation the severe valvular stenosis was confirmed. 'It was hoped that it had been relieved, but while the subclavian-pulmonary anastomosis was being closed, bleeding became severe and led to her death later in the day.

Necropsy. The heart was greatly enlarged and weighed $420 \mathrm{~g}$. The right atrium was large but otherwise normal. The atrial septum had failed to develop normally and showed a large defect, measuring $18 \times 12 \mathrm{~mm}$. without any trace of a valve flap. Below the defect there were two obvious ridges (Fig. 14). The upper was a remnant of the septum primum and the lower was an abnormal upper ridge of the septum secundum that seemed to be fused with the sinus septum; in addition, it seemed that it had been formed in an abnormal position. There were at least three other small defects in the septum primum, the largest being about $3 \times 1 \mathrm{~mm}$.

The right ventricle was greatly hypertrophied. The pulmonary valve formed from three cusps showed a dome-shaped stenosis of the usual type, with a small central opening that was no more than $2 \mathrm{~mm}$. Valvotomy had not, as generally, split this small opening, but had divided the valve at the side; this had certainly overcome the obstruction, but might have led to regurgitation. The pulmonary trunk was dilated (mean diameter $9 \mathrm{~mm}$. compared with $11 \mathrm{~mm}$. for the aorta).

The left side of the heart was normal. The subclavian-pulmonary anastomosis seemed to have been functioning well, but it had been ligated at her recent operation.

The liver was enlarged and showed some degree of fatty change and fibrosis.

\section{Pulmonary Valvular Stenosis with a Left-to-Right Shunt}

In addition to the cases described, many with a right-to-left inter-atrial shunt, there were 18 others where there was a left-to-right shunt as well as the pulmonary stenosis. Sometimes both conditions were recognized clinically, but more often only one or the other, and the combination was only vaguely suspected, or quite unsuspected, until after catheterization. The clinical diagnosis, 
and this generally agreed with the predominant lesion, was pulmonary stenosis in 6 , a left-to-right shunt in 8 , and both conditions in 4 patients.

Only one was cyanotic. She was found to have moderate pulmonary stenosis with a right-toleft shunt, probably through an atrial septal defect, and a larger left-to-right shunt, probably because most of the pulmonary veins drained into the right atrium. The other 17 were acyanotic. The cyanotic Case C1 and Cases A3, E1, and E2, of Table IX, have been fully reported by Deuchar and Zak, 1951 (Cases 1-4).

TABLE IX

Catheter Findings in Patients with Pulmonary Stenosis and a Left-to-Right Shunt

\begin{tabular}{|c|c|c|c|c|c|c|c|c|c|c|c|}
\hline \multirow{2}{*}{ Case No. } & \multirow{2}{*}{$\begin{array}{l}\text { Sex } \\
\text { and } \\
\text { age }\end{array}$} & \multicolumn{6}{|c|}{ Oxygen percentage saturation } & \multirow{2}{*}{$\begin{array}{l}\text { Systemic } \\
\text { flow } \\
\text { litres/min. }\end{array}$} & \multirow{2}{*}{$\begin{array}{l}\text { Pulmonary } \\
\text { flow } \\
\text { litres/min. }\end{array}$} & \multicolumn{2}{|c|}{ Pressures } \\
\hline & & S.V.C. & I.V.C. & R.A. & R.V. & P.A. & $\begin{array}{c}\text { Systemic } \\
\text { artery }\end{array}$ & & & R.V. & P.A. \\
\hline $\begin{array}{l}\text { C1 (O009) } \\
\text { A1 (1129) } \\
\text { A2 (O875) } \\
\text { A3 (P259) } \\
\text { A4 (H314) } \\
\text { A5 (O430) } \\
\text { A6 (CB27) } \\
\text { A7 (1116) }\end{array}$ & $\begin{array}{l}\text { F7 } \\
\text { F21 } \\
\text { M8 } \\
\text { M12 } \\
\text { F9 } \\
\text { M9 } \\
\text { F9 } \\
\text { M6 }\end{array}$ & $\begin{array}{l}\text { With } \\
71 \\
65 \\
68 \\
65^{*} \\
66 \\
54^{*} \\
74 \\
74\end{array}$ & $\begin{array}{l}\text { h atrial } \\
\begin{array}{|c|}72 \\
73 \\
63 \\
62 \\
69 \\
77 \\
68\end{array}\end{array}$ & 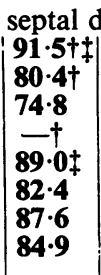 & $\begin{array}{l}\text { lefects } \\
89 \cdot 0 \\
72 \cdot 1 \\
71 \cdot 7 \\
82 \cdot 5 \\
89 \cdot 0 \\
88.7 \\
86 \cdot 3 \\
84.9\end{array}$ & $\begin{array}{l}\text { on anon } \\
89 \cdot 4 \\
74.9 \\
70 \cdot 0 \\
85.7 \\
85 \cdot 0 \\
84.6 \\
87.6 \\
86.2\end{array}$ & \begin{tabular}{|} 
nalous puln \\
86 \\
98 \\
98 \\
98 \\
92 \\
95 \\
94 \\
93
\end{tabular} & $\begin{array}{c}\text { ory venou } \\
4.9 \\
4.3 \\
4.0 \\
4.8 \\
4.0 \\
2.7 \\
6.3 \\
3.9\end{array}$ & $\begin{array}{r}\text { drainage } \\
9 \cdot 5 \\
5 \cdot 1 \\
4 \cdot 5 \\
13 \cdot 4 \\
12 \cdot 7 \\
10 \cdot 1 \\
14 \cdot 5 \\
7 \cdot 3\end{array}$ & $\begin{array}{r}68 / 7 \\
95 / 3 \\
63 / 3 \\
117 / 8 \\
62 / 0 \\
89 / 7 \\
49 / 0 \\
55 / 0\end{array}$ & $\begin{array}{l}35 / 12 \\
18 / 10 \\
21 / 5 \\
27 / 4 \\
20 / 9 \\
22 / 10 \\
24 / 6 \\
23 / 9\end{array}$ \\
\hline $\begin{array}{l}\text { B1 }(\text { O948) } \\
\text { B2 (P289) } \\
\text { B3 (O825) } \\
\text { B4 (O684) } \\
\text { B5 (O655) }\end{array}$ & $\begin{array}{l}\text { M25 } \\
\text { M5 } \\
\text { M12 } \\
\text { M17 } \\
\text { F19 }\end{array}$ & $\begin{array}{l}61 \\
71 \\
50 \\
66 \\
62\end{array}$ & $\begin{array}{l}\frac{63}{70} \\
65 \\
64\end{array}$ & \begin{tabular}{|l|}
$63 \cdot 5$ \\
$70 \cdot 6$ \\
$72 \cdot 8$ \\
$62 \cdot 6$ \\
66.0
\end{tabular} & $\begin{array}{l}\text { With ve } \\
\begin{array}{|l|}\mathbf{7 5} \cdot 8 \\
\mathbf{8 2} \cdot \mathbf{5} \\
\mathbf{8 8 . 8} \\
\mathbf{8 4 . 8} \\
\mathbf{7 3 . 8}\end{array}\end{array}$ & $\begin{array}{l}\text { ntricul } \\
74 \cdot 8 \\
81 \cdot 1 \\
84 \cdot 5 \\
85 \cdot 4 \\
79 \cdot 0\end{array}$ & $\begin{array}{c}\text { septal de } \\
94 \cdot 5 \\
93 \\
95 \\
97 \\
98\end{array}$ & $\begin{array}{l}4 \cdot 4 \\
2 \cdot 9 \\
4 \cdot 9 \\
4 \cdot 5 \\
5 \cdot 4\end{array}$ & $\begin{array}{r}6 \cdot 5 \\
6 \cdot 1 \\
8 \cdot 1 \\
12 \cdot 7 \\
9 \cdot 5\end{array}$ & $\begin{array}{c}121 / 3 \\
72 / 0 q \\
110 / 0 \\
85 / 2 \uparrow \\
98 / 5\end{array}$ & $\begin{array}{l}22 / 10 \\
36 / 16 \\
23 / 8 \\
50 / 15 \\
30 / 7\end{array}$ \\
\hline $\begin{array}{l}\text { D1 (O532) } \\
\text { D2 (O576) }\end{array}$ & $\begin{array}{l}\text { F29 } \\
\text { M13 }\end{array}$ & $\begin{array}{l}58 \\
63\end{array}$ & $\begin{array}{l}51 \\
64\end{array}$ & $\begin{array}{l}60 \cdot 0 \\
65 \cdot 3\end{array}$ & $\mid \begin{array}{l}59.0 \\
68.0\end{array}$ & \begin{tabular}{|l|}
$85 \cdot 5$ \\
$82 \cdot 6$
\end{tabular} & $\begin{array}{l}99 \\
97\end{array}$ & $\begin{array}{l}3 \cdot 1 \\
3 \cdot 4\end{array}$ & $\begin{array}{l}9 \cdot 0 \\
6 \cdot 8\end{array}$ & $\begin{array}{l}158 / 10 \\
115 / 0\end{array}$ & $\begin{array}{l}36 / 16 \\
45 / 22\end{array}$ \\
\hline $\begin{array}{l}\text { E1 (P299) } \\
\text { E2 (O512) } \\
\text { E3 (P248) }\end{array}$ & \begin{tabular}{|l|} 
M10 \\
M6 \\
F12
\end{tabular} & $\frac{67^{*}}{61}$ & $\overline{62}$ & $\begin{array}{l}64 \cdot 0 \\
63 \cdot 0 \\
61 \cdot 0\end{array}$ & $\begin{array}{l}70 \cdot 2 \\
75.9 \\
76.7\end{array}$ & $\mid \begin{array}{l}78.9 \\
77.2 \\
75.0\end{array}$ & $\begin{array}{c}\text { mixed ce } \\
97 \\
95 \\
94\end{array}$ & $\begin{array}{l}3 \cdot 4 \\
3 \cdot 2 \\
5 \cdot 0\end{array}$ & $\begin{array}{r}5 \cdot 5 \\
5 \cdot 7 \\
10 \cdot 0\end{array}$ & $\begin{array}{l}48 / 0 \\
89 / 4 \\
56 / 0\end{array}$ & $\begin{array}{l}22 / 10 \\
35 / 8 \\
37 / 16\end{array}$ \\
\hline
\end{tabular}

* Left S.V.C. draining into R.A. through coronary sinus, as well as right S.V.C.

$\dagger$ ?Anomalous pulmonary venous drainage in the right atrium.

$\mp$ Catheter passed through atrial septal defect.

$\S$ Catheter passed through V.S.D. to aorta.

II ? Infundibular stenosis.

With Atrial Septal Defect or with Pulmonary Veins Draining into the Right Atrium (7). This included 4 cases where the clinical diagnosis was pulmonary stenosis and 3 where it was atrial septal defect, and in one of each of these groups the double diagnosis was suspected. In two of the former the pulmonary stenosis was severe (Cases A1 and A3, Table IX), but it was far from insignificant in the others, although in two of them it was unexpected until catheterization.

It is certain that there was a left-to-right shunt into the right atrium in six, and almost certainly in the seventh, though no atrial specimen was obtained. But only in Case A4 was the shunt proved to be through an atrial septal defect, and in three there was some reason for thinking that it might be due to pulmonary veins draining into the right atrium; in one (Case A3) the evidence for this was good, and it was thought that all the pulmonary veins might empty in this way, but in the other two (Cases A5 and A1) the only evidence was that the right atrial pressures were rather high, 10/4 and 8/4. In two of these three (Cases A3 and A5) there was a persistent left superior vena cava that drained into the right atrium through the coronary sinus.

In the five cases where the pulmonary stenosis seemed most important the electrocardiogram was what might be expected for this, though none showed the pattern of $T$ inversion across the chest leads except one where it reached V2 only, and in two the evidence of right ventricular preponderance was slight. In the 
other two, where the left-to-right shunts seemed more important, one had typical and one atypical partial right bundle branch block.

Many of the cases of simple pulmonary stenosis with a right-to-left interatrial shunt had a normal foramen ovale with a valve flap, so that an earlier left-to-right shunt was not possible; but at least three of those with necropsy could have had a left-to-right shunt earlier, because there was a true septal defect; there was, however, no clinical evidence that they had ever had such a shunt.

Possibly the cases that presented clinically as atrial septal defects may, as the effect of the pulmonary stenosis increases, reverse the interatrial shunt, but we have seen no proved example of this. Abrahams and Wood (1951) described five cases with a left-to-right shunt (their Table VIII) similar to ours, but all with pulmonary stenosis that was only slight. They also described seven cases with pulmonary stenosis and a right-to-left interatrial shunt (their Table IX), but there is no proof that these had a left-to-right shunt earlier and they resemble those included in the body of our paper.

Operation has not been advised in any of these patients as in all the pulmonary blood flow was increased by the left-to-right shunt; but it was not much increased in Cases A1 and A2, and if the right ventricular strain increases, valvotomy should be advised.

With Ventricular Septal Defects (5). These cases are by definition excluded from the group of simple pulmonary stenosis, but seem worth short consideration. The clinical diagnosis was ventricular septal defect in three, pulmonary stenosis in one, and both conditions were suspected in one though the left-toright shunt seemed more important than the stenosis. In the two latter (Cases B1 and B3) the pulmonary stenosis was severe, as judged by right ventricular pressures of 121 and 110 , but it was not insignificant in the other three with pressures of 98,85 , and $72 \mathrm{~mm}$. $\mathrm{Hg}$. In spite of these high pressures none showed the pattern of $T$ inversion across the chest leads and, in two of them, the $R$ waves were not predominant in the chest leads till V4R was reached (Cases B3 and B4).

One of these had heart block that was generally complete and, in spite of an arterial $\mathrm{O}_{2}$ saturation of 95 per cent, had some evidence of cyanosis at times; this may have been peripheral but as the pressure in the right ventricle was close to that in the aorta, 110 and 123 respectively, there may sometimes have been a right-to-left shunt and Fallot's tetralogy with a trivial degree of over-riding of the aorta is difficult to exclude.

Any of these patients might develop a condition indistinguishable from Fallot's tetralogy if the pressure on the right side rises enough to reverse the shunt, because this depends on the relative pressures and not on the mere presence of an over-riding aorta. Considering the high pressures, it is surprising that none of them has done so, and the condition is very like Fallot's tetralogy where the degree of cyanosis (and of overriding aorta) is minimal, or indeed where there has been a very successful valvotomy; but since this paper was written we think that Case B1 is doing so and operation is being considered.

Otherwise, operation has not been advised in any of these patients. In spite of the severity of the stenosis in some of them, the pulmonary blood flow is increased, sometimes greatly so, and they seem best left with their present balance as pulmonary valvotomy might increase the left-to-right shunt unduly.

With Patent Ductus Arteriosus. There were two examples of this combination. Only one had a continuous murmur and in her the patent ductus was diagnosed easily, but the pulmonary stenosis was added with less certainty on clinical grounds, though it was proved to be severe on catheterization, the pressure gradients across the pulmonary valve falling from $158 / 10$ to $36 / 16$ (Case D1). She had gross right ventricular preponderance with the pattern of $\mathrm{T}$ inversion across to $\mathrm{V} 3$ and a very large heart (c.t.r. 68 per cent). As she was 34 and getting on well, operation was thought too dangerous, but two years later she had become much worse and valvotomy was successfully carried out by Mr. Brock, the patent ductus being tied at the same time: the result has been very good and the heart has become much smaller.

The second, a boy, aged 13, was diagnosed clinically as uncomplicated pulmonary stenosis with slight symptoms and a heart of normal size. No continuous murmur was heard, but an increase of the $\mathrm{O}_{2}$ saturation from 68 per cent in the right ventricle to 82 in the pulmonary trunk seems adequate evidence of a patent ductus arteriosus. It is hard to see why there was no murmur in diastole when the pressure in the pulmonary artery was hardly raised (Case D2).

Anomalous Mixed Conditions. There were three cases where the clinical diagnosis was a left-to-right shunt, possibly a patent ductus, and where pulmonary stenosis was diagnosed only at catheterization. They were a curious group with varied and complicated lesions.

In one boy, the left-to-right shunt was thought to be through an aortico-pulmonary septal defect, and the pulmonary stenosis was slight (Case E1). In the second boy, the diagnosis was congenital aneurysm of the sinus of Valsalva that had probably ruptured and produced aortic incompetence during an attack of bacterial endocarditis; the pulmonary stenosis was moderately severe (Case E2). The third was even more 
complex. Ligation of a patent ductus failed to cause the disappearance of the "continuous" murmur, which several observers before operation had thought was the to-and-fro murmur of aortic incompetence. She was re-catheterized, and the successful closure of the patent ductus was confirmed; in addition there was a slight pulmonary valvular stenosis and a left-to-right shunt into the right ventricle, which makes it likely that her gross aortic incompetence was due to an abnormal aortic cusp associated with a defect of the ventricular septum (Case E3).

\section{SUMMARY}

Simple pulmonary stenosis-valvular stenosis with a closed ventricular septum-is common. The slighter cases must be diagnosed by physical signs alone, and only the more severe can be expected to show hæmodynamic effects of the stenosis. A rough systolic murmur and thrill in the pulmonary area should suggest the diagnosis, especially if there is a prominent pulmonary arc and some enlargement of the right ventricle.

In the slighter cases, the prognosis is excellent. I have recently seen two such patients-one a man of 66 in whom I made the diagnosis twenty years ago and the symptoms have been trivial till the last few months, and the other a man of 38, with an unusual degree of peripheral cyanosis, who leads a normal life in every way and served as an infantry officer during the war, when he was able to take part in quite active sports.

Central cyanosis is always due to a right-to-left inter-atrial shunt; it adds to the gravity of the condition but hardly changes the general picture. The two groups were analysed separately, but the findings were so similar that they have been considered together. A patient may develop cyanosis at any age, but often not until early adult life. Some cyanotic patients squat but much fewer than among those with Fallot's tetralogy.

In most cases the heart is of normal size, but as the condition becomes more severe it may become very large; this is a late sign. The aortic arch is nearly always left-sided.

Right ventricular preponderance may be absent from the electrocardiogram but, if so, the stenosis is slight and unimportant. It is present in moderate cases and, as the stenosis becomes more severe, there is a characteristic pattern of right ventricular strain with deep $\mathrm{T}$ inversion spreading across the chest leads to V4 or further. This pattern and giant $P$ waves generally show the need for pulmonary valvotomy.

The right atrial pressure shows some correlation with the right ventricular pressure. A giant $a$ wave in the jugular pulse and unusually large $P$ waves are found with the higher atrial pressures. The right ventricular systolic pressure is generally between 100 and $180 \mathrm{~mm}$. $\mathrm{Hg}$ in the cyanotic cases. It is just as high in many acyanotic cases, but there are many others where it is only slightly or moderately raised, between 50 and $80 \mathrm{~mm}$. These patients have few or no symptoms and there is no indication for pulmonary valvotomy. The cardiac output does not fall till a fairly advanced stage, so that reflex peripheral vaso-constriction is probably responsible for the peripheral cyanosis that is often seen.

Thirteen hearts were available for describing the pathological anatomy. The stenosis was always at the valve cusps which were fused to form a dome-like diaphragm with a small central opening. The pulmonary trunk was dilated. The rest of the heart was generally normal except for the gross hypertrophy of the right ventricular muscle which was thicker than the left, and the defect of the septum. There was always an anatomical basis for a right-to-left shunt when the patient was cyanotic. Generally this was an unsealed foramen ovale, but often a small atrial septal defect and occasionally a large one.

A few other cases where pulmonary valvular stenosis was complicated by an additional lesion causing a left-to-right shunt are described shortly.

The results of pulmonary valvotomy will be discussed in a subsequent paper. A right ventricular pressure over $100 \mathrm{~mm} . \mathrm{Hg}$; right ventricular strain in the cardiogram; a giant $a$ wave in the jugular pulse; severe symptoms; and much enlargement of the heart, perhaps in this order, are signs of increasing severity. If any of the last four are present the operation of valvotomy is generally 
indicated at once, though even in the later stages it may still produce dramatic improvement. Moderate or increasing disability without these signs suggests the need for catheterization to measure the right ventricular pressure, and if this is above $100 \mathrm{~mm}$. $\mathrm{Hg}$ it is probably wise not to defer operation.

I am grateful to Mr. R. C. Brock and to Dr. C. G. Baker for asking me to see some of these patients, and to Mr. Brock for his surgical treatment of many of them. I should like to thank Dr. Deuchar and Dr. Shephard for the results of cardiac catheterization, Dr. Paul Wood and the Registrars at the Heart Hospital for four of these, and Drs. Allanby, Brinton, Hudson, and Baylis for help with the pathological anatomy, and Dr. Hudson for Fig. 16 and 17 as well; also Miss M. J. Waldron for the drawings and Mr. Engel for most of the photographs.

\section{REFERENCES}

Allanby, K. D., and Campbell, M. (1949). Guy's Hosp. Rep., 98, 18.

Abrahams, D. G., and Wood, P. (1951). Brit. Heart J., 13, 519.

Balsac, H. de, Métianu, C., Durand, M., and Dubost, Ch. (1954). Traité des Cardiopathies Congéntiales. Masson et Cie, Paris.

Baker, C. G., Brock, R. C., Campbell, M., and Suzman, S. (1949). Brit. Heart J., 11, 170.

Brock, R. C., and Campbell, M. (1950). Brit. Heart J., 12, 377.

Brown, J. W. (1939). Congenital Heart Disease. John Bale Ltd., London.

Campbell, M. (1948). Guy's Hosp. Rep., 97, 1.

- and Kauntze, R. (1953). Brit. Heart J., 15, 179.

Chamberlain, F. N., and Hay, J. D. (1939). Brit. Heart J., 1, 105.

Currens, J. H., Kinney, T. D., and White, P. D. (1945). Amer. Heart J., 30, 491.

Deuchar, D. C., and Zak, G. A. (1952). Guy's Hosp. Rep., 101, 1.

Dow, J. W., Levine, H. D., Elkin, M., Haynes, F. W., Hellems, H. K., Whittenberger, J. W., Ferris, B. G., Goodale, W. T., Harvey, W. P., Eppinger, E. C., and Dexter, L. (1950). Circulation, 1, 267.

Eakin, W. W., and Abbott, M. F. (1933). Amer. J. med. Sci., 186, 860.

Joly, F., Folli, G., and Carlotti, J. (1952). Arch. Mal. Caur, 45, 1108.

Kreutzer, R. (1953). VII International Congress of Pædiatrics.

Marquis, R. M. (1951). Brit. Heart J., 13, 89.

Moschcowitz, E. (1952) Ann. intern. Med., 36, 933.

Peacock, T. B. (1866). Malformations of the Human Heart. 2nd ed. London.

Selzer, A., and Carnes, W. H., (1953). Amer. Heart J., 45, 382.

- Noble, C. A., Higgins, W. H., and Holmes, R. O. (1949). Amer. J. Med., 6, 3.

Soulié, P., Joly, F., Carlotti, J., Piton, A., and Thuillez, B. (1953). Arch. Mal. Caur, 46, 695.

Taussig, H. (1947). Congenital Malformations of the Heart. Commonwealth Fund, New York.

White, P. D. (1951). Heart Disease. 4th ed. The MacMillan Co., New York.

Wood, P. (1950a). Brit. med. J., 2, 639 and 693.

(1950b). Diseases of the Heart and Circulation. Eyre and Spottiswode, London.

, and Selzer, A. (1939). Brit. Heart J., 1, 81.

Zuckermann, R., Cisneros, F., and Novelo, S. (1951). Arch. Inst. Cardiol., Mexico, $21,61$.

\section{APPENDIX}

Since writing this, a fourteenth case that was not included in Table VIII has come to necropsy. A man, aged 37, who was known to have had a murmur since he was four years old, led an active life with no symptoms and played vigorous tennis until he was 30 . He then became progressively more breathless and from the age of 33 was almost an invalid with auricular fibrillation and a very large liver, and later with recurrent ascites that needed tapping. The heart was enormous, c.t.r. 70 (m.t.d. $21 / 30 \mathrm{~cm}$.) and there were the usual signs of pulmonary stenosis. Catheterization a year before showed a pressure of $120 / 15$ (mean pressure $43 \mathrm{~mm} . \mathrm{Hg}$ three years earlier) in the right ventricle and 15 in the pulmonary artery: the arterial $\mathrm{O}_{2}$ saturation had fallen from 97 to 93 per cent. We are indebted to Dr. Vernejoul of Marseilles for these reports. The electrocardiogram showed auricular fibrillation and signs of right ventricular preponderance and partial right bundle branch block. The aortic arch was left-sided.

It was thought that pulmonary valvotomy was his only hope, even though the cardiac cirrhosis of the liver might have progressed too far for recovery in this direction. This was performed successfully by Mr. R. C. Brock without any unusual difficulty: the pressure in the right ventricle was reduced from $84 / 14$ to $38 / 16 \mathrm{~mm}$. Hg. Mr. Brock was surprised at the thinness of the wall of the right ventricle compared with other cases of simple pulmonary stenosis, but this was probably due to the great dilatation of the heart. His condition seemed good after the operation, but he died suddenly on the third day after, presumably from ventricular fibrillation. 
Necropsy. Permission was given for a limited examination only. The pericardial sac contained $300 \mathrm{ml}$. of cloudy fluid and there was a generalized fibrinous pericarditis. The heart weighed $625 \mathrm{~g}$. and looked enormous, due largely to dilatation of the right atrium and both ventricles. There was some muscle hypertrophy but it was less than has been usual in the right ventricle. The arrangement of the great veins and arteries was normal and there was no communication between the two sides of the heart. The tricuspid valve was grossly dilated and slightly opaque. The pulmonary valve had three fused cusps and looked as if, before its surgical division, it had been of the usual dome shape and no more than from 2 to $3 \mathrm{~mm}$. in diameter. The pulmonary trunk was greatly dilated, $35 \mathrm{~mm}$. in diameter $20 \mathrm{~mm}$. above the valve, compared with an aorta $18 \mathrm{~mm}$. in diameter just above the valve. The aortic valve was normal. The mitral valve was normal except that it was a little dilated. The coronary arteries were remarkably free from atheroma and were normal except that the orifice of the right artery was double, being divided by a fibrous band.

There was some partial collapse of the lower lobe of the left lung. There was cardiac cirrhosis of the liver. I am indebted to Dr. J. B. Enticknap for the account of the necropsy and he informed me that he had rarely if ever seen such an advanced degree of cardiac cirrhosis. 